\title{
Anticipated Inversion and Visibility Conditions over Glacier Bay with a Changing Climate
}

\author{
Nicole Mölders ${ }^{1 *}$, Scott Gende ${ }^{2}$ \\ ${ }^{1}$ Department of Atmospheric Sciences, Geophysical Institute and College of Natural Science and Mathematics, \\ University of Alaska Fairbanks, Fairbanks, USA \\ ${ }^{2}$ National Park Service, Glacier Bay Field Station, Juneau, USA \\ Email: cmoelders@alaska.edu
}

Received 17 April 2015; accepted 19 May 2015; published 22 May 2015

Copyright (C) 2015 by authors and Scientific Research Publishing Inc.

This work is licensed under the Creative Commons Attribution International License (CC BY).

http://creativecommons.org/licenses/by/4.0/

(c) (i) Open Access

\section{Abstract}

A RCP4.5 simulation from the Community Earth System Model was downscaled by the Weather Research and Forecasting Model, inline coupled with chemistry, to examine how climate change may affect inversions and visibility in Glacier Bay in the presence of cruise-ship visitations. Mean downscaled climate conditions for the tourist seasons for 2006-2012 were compared with downscaled conditions for 2026-2032 with identical cruise-ship entries and operating conditions thereby isolating pollutant retention and visibility differences caused by atmospheric climate change. Notable changes in future temperature, humidity, precipitation, and wind-speed occurred for large areas of Southeast Alaska and the Gulf of Alaska, although the anticipated differences were less pronounced in Glacier Bay due to the presence of the large glaciers and ice fields. While increased sensible heat and water vapor in the atmospheric boundary layer contributed to on average $4.5 \mathrm{~h}$ reduced inversion duration in Glacier Bay, the on average $0.23 \mathrm{~m} \cdot \mathrm{s}^{-1}$ reduced wind speeds increased inversion frequency by $4 \%$ on average. The future on average wetter conditions and altered precipitation patterns in Glacier Bay affected the removal of gases and particulate matter emitted by cruise ships locally or advected from areas outside the park. Season-spatial averaged visibility in Glacier Bay remained the same. However, visibility was degraded in the future scenario later in the season and slightly improved during spring. The warmer conditions contributed to decreased visibility indirectly by tieing up less $\mathrm{NO}_{2}$ in PAN and increasing biogenic $\mathrm{NO}_{\mathrm{x}}$ emissions. The wetter conditions contributed to reduced visibility in the last third of the tourist season.

\section{Keywords}

Glacier Bay National Park, Inversions, Visibility, CESM, WRF/Chem, Downscaling

\footnotetext{
"Corresponding author.
} 


\section{Introduction}

Climate change is expected to have direct and profound impacts on the hydrological and biogeochemical cycles, species abundance and distribution, and the physical template of polar and sub-polar regions [1]. However, impacts from climate change are also likely manifested from rapidly increasing human use of these regions with increased opportunities for hydrocarbon development, tourism, and commercial shipping [2] [3]. Thus, marine resource and land-management agencies within these regions are tasked with management decisions in the face of the anticipated changes, a particularly difficult task due to the uncertainty in how ecosystems function, the uncertainty attributed to assumed changes in greenhouse gases and other climate forcers, and because managers cannot fundamentally change the drivers of these changes. Thus, managers focus on "adaptability" and adjusting management targets as a primary strategy to address impacts from changing climate.

The US National Park Service (NPS) is one such agency that must address the issue of climate change. Historically, management targets within national parks have been guided by the goal of representing “... vignettes of primitive America" [4]. Consequently, historical conditions often serve as a management baseline for contemporary and future management goals. Yet this philosophical foundation has been reconsidered in the face of climate change requiring managers to rethink what is "natural" and "natural variability" [5]. These decisions become particularly difficult when visitation or visitor use can alter park resource conditions, as climate change shifts the baseline from which to evaluate the magnitude of the impact. The visitation-conservation mandate is thus often at the crux of difficult near- and long-term management decisions.

Management uncertainty in the face of changing climate is perhaps no more pronounced than in Glacier Bay National Park and Preserve, one of the largest national parks in the US, and part of the Kluane/Wrangell-St. Elias/Glacier Bay/Tatshenshini-Alsek World Heritage Site, one of the largest contiguous protected areas in the world. Glacier Bay National Park (hereafter Glacier Bay, or "the park") was founded largely to conserve scientific opportunities provided by the repeated and rapid advance and retreat of tidewater glaciers, fed from the large Brady Icefield, resulting in unprecedented opportunities to study marine and terrestrial landscape scale evolution subject to these glacial dynamics [6]. Thus, management understanding of the park's ecosystems and biota are a naturally dynamic nature of the resources under their jurisdiction. Add the dynamics of climate change to the already dynamic nature of the park resources and it is difficult to generate natural resource management targets from which to assess impacts from visitation.

In Alaska and across the northern hemisphere, climate change has resulted in rapid and unprecedented loss of ice-sheet thickness [7]. These contemporary, and the anticipated future, conditions increasingly serve as a catalyst for "last chance" tourism [8] wherein people choose to visit destinations like Glacier Bay that are likely to be lost or fundamentally different in the near future. This paradox of climate change and tourism [8] is particularly pronounced in Glacier Bay.

Most (>95\%) of the visitors to the park arrive aboard large cruise ships which emit primary particles and precursor gases like sulfur dioxide $\left(\mathrm{SO}_{2}\right)$, nitrogen oxides $\left(\mathrm{NO}_{\mathrm{x}}\right)$, and non-methane volatile organic compounds (VOC) [9] that form secondary particles by gas-to-particle conversion [10]. Particulate matter encompasses sulfate, nitrate, organic carbon, and elemental carbon, among others. Many of these primary and secondary particles may take up water vapor and form haze thereby reducing visibility [11].

To protect the ecosystems, wildlife, and the pristine air and water conditions in Glacier Bay as well as the visitor experience, the NPS has limited the cruise-ship entries to two per day between June 1 and August 31, and a seasonal quota of 153 ship entries during the 92-day June to August peak season. This restriction and the rising sustained demand for glacier-viewing cruises has increased cruise-ship traffic in less and non-protected tidal glacier fjords of Southeast Alaska [11].

Located within the southeastern panhandle of Alaska, Glacier Bay national park has a mid-latitude oceanic and subarctic oceanic climate (Köppen-Geiger classification $C f b, C f c$ ). The park encompasses highly complex terrain spanning the estuaries immediately adjacent to the open North Pacific Ocean, to high mountainous peaks of about $4572 \mathrm{~m}$ within the Fair Weather Mountains, and the steep Y-shaped fjord called Glacier Bay where most of the tourism occurs. Inversions form on a regular basis in the fjords and over the bay at-large during the summer coincident with when cruise-ship visits (May-September) [12].

While emissions from cruise ships did not appreciably generate air-pollution issues in Glacier Bay averaged across the season from the perspective of trace-gas concentrations and particulate matter, air-quality issues, in- 
cluding haze formation were increased dramatically on a number of days [11], particularly under conditions of sustained inversions [12]. While gas-to-particle formation occurs naturally, even in the pristine atmosphere [10], these processes are enhanced on all days when ships enter Glacier Bay [11]. In fact, the impacts were greatest on days when inversions occurred, as they trapped pollutants for up to several days [11] [12]. Build-up of pollutants and haze runs counter National Park Service policy of conserving air resources and viewsheds unimpaired and likely negatively affects visitor experience.

Various climate-model projections suggest increases in humidity, cloudiness and precipitation in Alaska will result from changes in the atmospheric path of the water cycle [13] [14]. These changes in atmospheric conditions under which cruise ships produce emissions in Glacier Bay can thus affect visibility by altered ventilation (e.g., wind speed, mixing depth, convection, frontal passages), chemical production and loss rates, precipitation scavenging, dry deposition, and biogenic emissions [10] [15].

Given the complex fate of emissions and the dependency of atmospheric chemistry on weather, any assessment of management decisions regarding summer cruise-ship impacts on protected areas first requires determining what the future baseline would be without any cruise-ship emission changes. For long-term planning, impact assessment should also include regional climate change because many air contaminants are sensitive to the local weather conditions [15]-[17]. For example, photolysis rates, chemical reactions rates, and aerosol formation depend on local conditions like actinic flux, temperature, and atmospheric water-vapor content [10]. Furthermore, indirect effects may occur such as 1) temperature changing biogenic emission fluxes, 2) aerosols and clouds affecting actinic fluxes, 3) aerosols affecting cloud and precipitation formation, as well as 4) various removal processes for contaminants [18]. Consequently, downscaling of climate-model data over the area of interest with an air-quality model [19] [20] for a past and future period has proved to be of considerable values in climate-change assessment [17] [19]-[22].

The Community Earth System Model (CESM) [23] is able to simulate meteorological quantities relevant for air quality [24]. CESM has a cold bias in the Rocky Mountains and a warm bias in their lee. Recent studies further demonstrated that downscaling of CESM simulations assuming the Intergovernmental Panel for Climate Change (IPCC) Representative Concentration Pathway 4.5 (RCP4.5) provided reasonable results [25]. The Weather Research and Forecasting model [26] inline with chemistry packages (WRF/Chem) [27] [28] has also been found to simulate meteorological quantities and air quality in Alaska well [29]-[31]. Downscaling of CESM simulations assuming the RCP4.5 with WRF/Chem produced acceptable climatologies for Southeast Alaska for the June, July, August and summer climate of 2006-2012. Evaluation by gridded blended sea-wind speeds and Climate Research Unit (CRU) 3.12 data [32] indicated bias (simulated minus observed) of $0.7 \mathrm{~m} \cdot \mathrm{s}^{-1}$, $-1.1^{\circ} \mathrm{C},-4.9^{\circ} \mathrm{C}, 13 \%$, and $110 \mathrm{~mm}$ for $10 \mathrm{~m}$ wind speeds over water, and $2 \mathrm{~m}$ temperatures, diurnal temperature ranges, relative humidity, and accumulated precipitation over land, respectively. Evaluation by data from 42 surface meteorology sites revealed that downscaled climatologies showed similar shortcomings (dampened diurnal temperature range, overestimation of wind speed over land) as are known from numerical weather prediction [33]. Both CESM and WRF underestimate precipitation in Southeast Alaska at the first barrier and overestimate precipitation in the rain shadow [33] [34]. The downscaling reproduced mesoscale responses known to occur in the region [12] [33].

Based on the above studies, downscaled CESM data for 2026-2032 should fall within similar accuracy. Therefore, we used CESM data and WRF/Chem to downscale regional climate over Southeast Alaska to examine the near-term impacts of climate change on inversions, air quality and visibility during tourist seasons over Glacier Bay waters. To achieve our goal we determined the inversion and visibility climatologies from downscaled CSEM data for the length of seven past (2006-2012) and seven future (2026-2032) tourist seasons (May 15 to September 15), and analyzed them for changes.

\section{Experimental Design}

\subsection{WRF/Chem Setup}

WRF/Chem used the same physical and chemical packages as in [11] [12] [33]. In sum, cloud processes on the resolvable and cumulus scale were considered by the WRF-Single-Moment 5-class scheme [35] and a furtherdeveloped version of the Grell-Dévényi cumulus-ensemble scheme [36], respectively. The Goddard two-stream multi-band scheme [37] and the Rapid Radiative Transfer Model [38] served to calculate shortwave and long- 
wave radiation processes, respectively. Cloud- and aerosol-radiation feedbacks followed [39]. Surface and atmospheric boundary layer (ABL) processes were calculated following [40]. A modified version of the NOAH land-surface scheme [41] served to determine the exchanges of momentum, heat and matter at the atmospheresurface interface. This scheme also solves prognostic equations for four layers $(0-0.1 \mathrm{~m}, 0.1-0.4 \mathrm{~m}, 0.4-1 \mathrm{~m}$, $1-2 \mathrm{~m}$ ) for soil-temperature and soil-moisture, and diagnosed frozen ground conditions. Its snow model considers fractional snowcover. The NOAH land-surface scheme also considers fractional sea-ice and is optimized to treat glacial conditions [26].

The Regional Acid Deposition Model version 2 chemical mechanism [42] applied photolysis rates calculated inline following [43]. Dry deposition of gases was determined following [44] with the modifications for Alaska [30]. The Modal Aerosol Dynamics Model for Europe [45] and Secondary Organic Aerosol Model [46] accounted for aerosol dynamics, physics, chemistry, some aqueous phase reactions, and aerosol removal. Biogenic emissions were calculated depending on the meteorological and soil conditions following [47] [48].

WRF/Chem used the activity-based anthropogenic emissions of 2008 [11] in all simulations. The simulations assumed 225 cruise ships entered Glacier Bay per season and proceeded at an average speed of $8.58 \mathrm{~m} \cdot \mathrm{s}^{-1}(16.7$ kts) to the west arm of the fjord, remained for several hours, and then proceeded back down the bay, exiting 10 12 hours later (see also [49]).

\subsection{Simulations}

The CESM data stem from a RCP4.5 simulation ran in "future mode" after its model year 2005 [50]. The RCP4.5 represents a moderate mitigation scenario assuming to reach a $4.5 \mathrm{~W} \cdot \mathrm{m}^{-2}$ climate forcing in 2100 . An assessment of the CESM performance can be found in [51].

The CESM data served as the initial and boundary conditions for WRF/Chem to provide a fine-scale resolution of climate change over Southeast Alaska. We used analysis data of snow, soil-temperature and moisture, and sea-surface temperature (SST) conditions of 2008 for all runs. Idealized vertical profiles of Southeast Alaska background concentrations served to initialize the chemical fields and as chemical lateral boundary conditions for all WRF/Chem simulations.

Cruise-ships make up a marginal fraction of the world's fleet [52]. Thus, the contribution of cruise ships in Southeast Alaska (29 in 2008) is negligible compared to the total ship emissions worldwide. The same is true even under the assumption of the moderate mitigation of emissions assumed in the RCP4.5. Consequently, we can downscale RCP4.5 CESM data with WRF/Chem. To assess the future impacts of climate change on visibility and inversions, we assumed the activity-based ship emissions of 2008 for all years [11]. This experimental setup ensured that any changes in air composition, visibility and inversion conditions, and thus ship-emission impacts in Glacier Bay, were due to atmospheric climate change only.

The WRF/Chem domain was centered at 58.5N, 135.5W (Figure 1) and encompassed Southeast Alaska and part of the Gulf of Alaska with a $7 \mathrm{~km}$ increment. WRF/Chem used a vertically stretched grid of 28 layers to 100 $\mathrm{hPa}$. The domain was the same as used by [33] in their assessment of WRF/Chem's performance in downscaling CESM RCP4.5 data. These authors performed their simulation on $120 \times 120$ grid-points and their analysis on $110 \times 110$ grid-points, i.e. the five outermost grid-points were discarded to exclude lateral boundary effects. Doing so is common procedure in limited area numerical weather prediction. However, their analysis led to the recommendation to discard ten grid-cells from the analysis when downscaling. Thus, our analysis considered $100 \times 100$ grid-points when we referred to domain-wide changes. Spatially, however, our focus was on Glacier Bay National Park and Preserve in general and the Y-shaped fjord known as Glacier Bay specifically.

Like multiple years of observations are required to obtain visibility statistics for present climate [53], several years of CESM-WRF/Chem simulations are required to separate effects of climate change from interannual variability. To assess near-term inversion and visibility conditions over Glacier Bay under RCP4.5 conditions, we used a comparative approach wherein two methodologically consistent datasets representing the climate conditions at different periods for the tourist seasons of 2006-2012 (CTL) and 2026-2032 (SCE) were compared. These datasets were gained by downscaling of CESM data for these seasons with WRF/Chem. These WRF/Chemdownscaled data served to determine climatologies of various meteorological and chemical quantities for CTL and SCE. Hereafter, we call these simulations as well as the climatologies derived there from for 2006-2012 and 2026-2032 CTL and SCE, respectively. For a comparison of our CTL-simulations to observed climatology see [33]. Note that June, July and August of our control climate correspond to the climate of their experiment. 


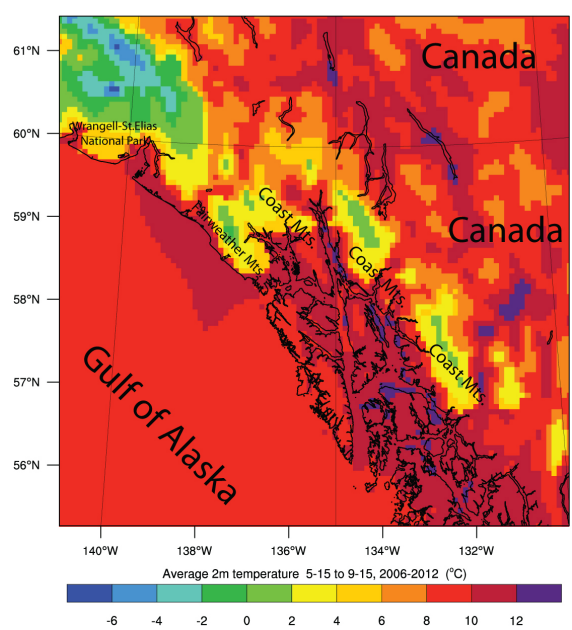

(a)

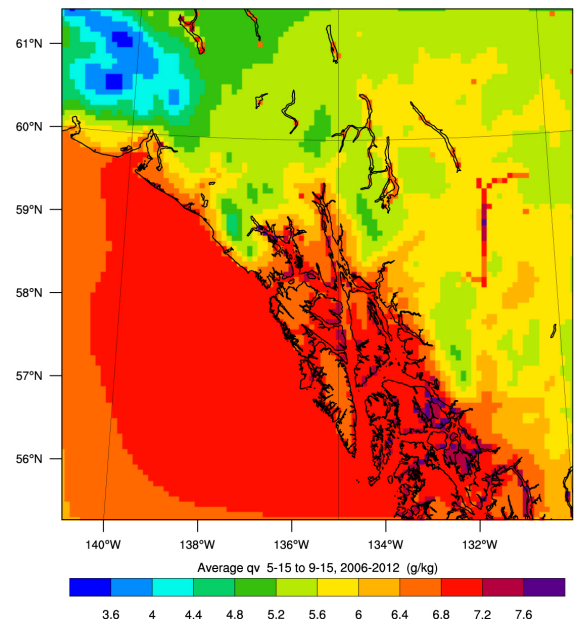

(c)

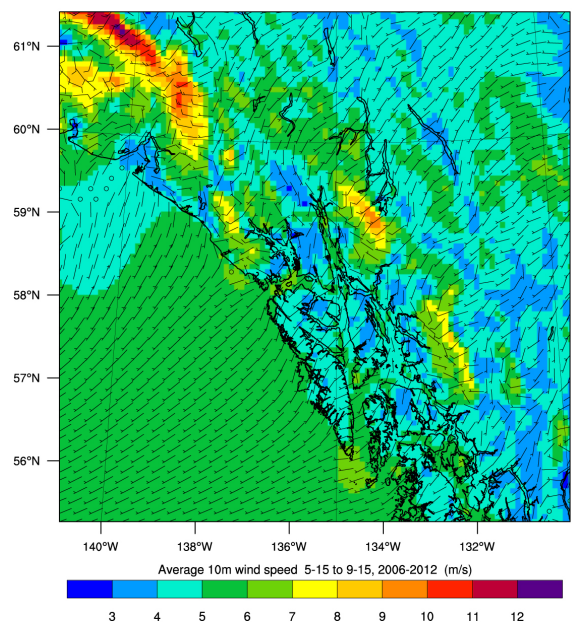

(e)

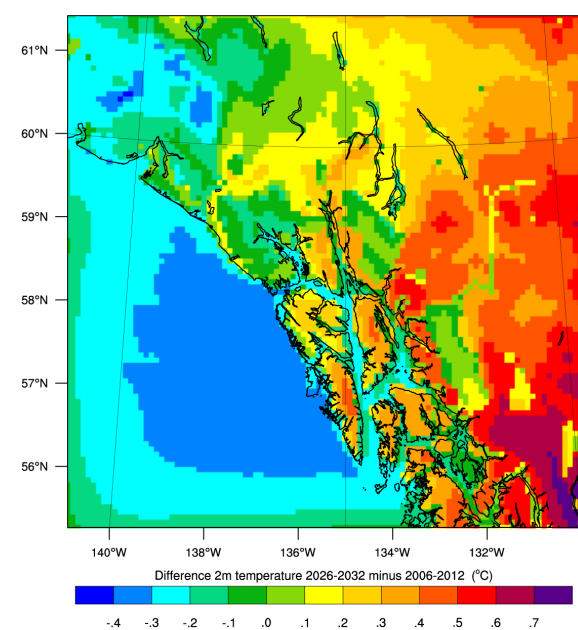

(b)

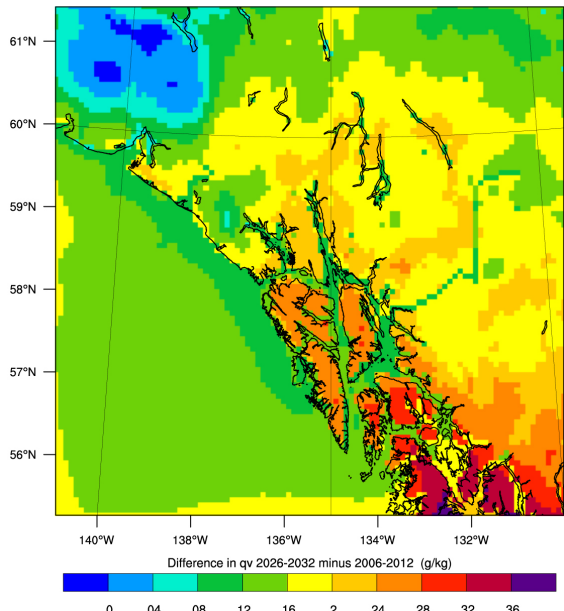

(d)

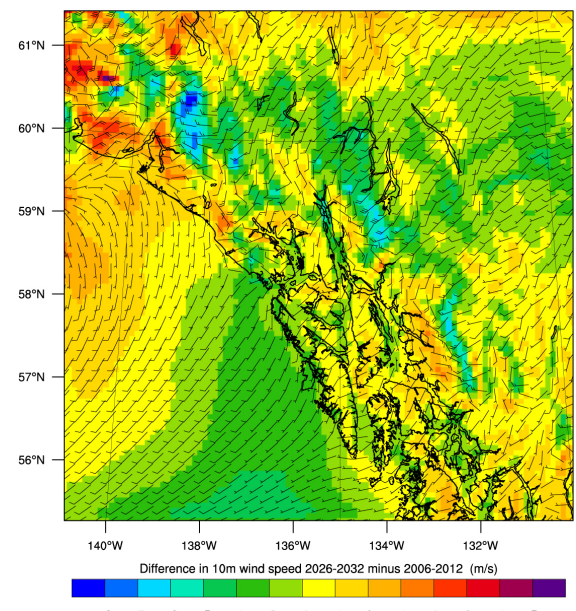

(f)

Figure 1. Mean ((a), (b)) $2 \mathrm{~m}$ air temperature, ((c), (d)) $2 \mathrm{~m}$ specific humidity, and ((e), (f)) $10 \mathrm{~m}$ wind speed (color shades) and direction (wind barbs in knots) for CTL ((a), (c), (e)) and SCE-CTL ((b), (d), (f))) over Southeast Alaska as obtained from downscaling of CESM RCP4.5 data with WRF/Chem. Note that (f) displays SCE wind barbs instead of differences for better comparability with CTL. 


\subsection{Analysis}

For our analysis, we mainly focused on mean changes in space and/or over the diurnal course and/or season. Following [54] the temporal standard deviations of meteorological quantities served to measure the interannual variability. The significance of changes was examined at the $95 \%$ confidence level using a two-tailed t-test allowing different variances. In the following, we used the word significant only in this context.

The assessment of visibility and inversion conditions in Glacier Bay followed [11] and [12], respectively. Following US Environmental Protection Agency (EPA) [53], we expressed visibility in terms of haze index (HI). An environmental lapse rate had to exceed $0.5^{\circ} \mathrm{C} \mathrm{km}^{-1}$ or more to qualify as an inversion. The algorithm checked for more than one inversion per grid column and time. We calculated the mean climatologies of inversion frequency, strength, thickness, and duration for all grid columns over Glacier Bay waters for CTL and SCE. Local climate change was quantified in terms of mean differences (SCE minus CTL) during the tourist season. In the following, we used past tense for the discussion of SCE results for clarity.

\section{Results}

\subsection{Meteorology}

In CTL, the 15 May-15 September tourist-season $2 \mathrm{~m}$ temperature means ranged between $6^{\circ} \mathrm{C}$ and $12^{\circ} \mathrm{C}$ over the Gulf of Alaska (Figure 1) and exceeded $8^{\circ} \mathrm{C}$ in the fjords of southeast Alaska. Over glacier-covered mountains, mean $2 \mathrm{~m}$ temperatures ranged from less than $-6^{\circ} \mathrm{C}$ for high terrain elevation to $6^{\circ} \mathrm{C}$ for low terrain elevation. Over large parts of Canada, $2 \mathrm{~m}$ temperature means varied from $6^{\circ} \mathrm{C}$ to more than $14^{\circ} \mathrm{C}$.

For anticipated future conditions, the general distribution of mean $2 \mathrm{~m}$ temperatures remained approximately the same as in CTL, save for some localized variances (Figure 1). The largest increases in mean $2 \mathrm{~m}$ temperatures occurred landward over Canada with more than $0.7^{\circ} \mathrm{C}$. This landward increase in $2 \mathrm{~m}$ air temperatures in response to climate change agrees with findings of other downscaling studies performed along the Pacific Coast (e.g. [55]). Mean $2 \mathrm{~m}$ temperatures decreased up to $0.4^{\circ} \mathrm{C}$ and $0.3^{\circ} \mathrm{C}$ or less over the Gulf of Alaska and most fjord waters, respectively. This decrease is likely an artifact from using the same SSTs for both episodes.

Keeping the SSTs the same ensured that changes were only due to atmospheric climate change. However, in nature, SSTs change with atmospheric temperature and vice versa. Keeping the SSTs the same in both episodes meant that over water, keeping the SSTs of the baseline cooled the near-surface atmosphere of the 2026-2032 seasons slightly. Modeling studies in the North Pacific suggested that east of the date line, $2 \mathrm{~m}$ air temperatures maintain SSTs, but SSTs affect $2 \mathrm{~m}$ air-temperature variability marginally [56]. Therefore, one may assume that using the same SSTs for the past and future may have marginal impact on our overall findings for Glacier Bay.

Over land, we used the same soil and snow initialization for both episodes as well. The soil and snow-temperature and moisture conditions in response to climate change were simulated by WRF/Chem as part of the downscaling. Over the Alexander Archipelago, mean $2 \mathrm{~m}$ air temperature increases showed a north-south gradient with strongest increases in the South (Figure 1). These findings suggest that the glaciers, icefields, and water surfaces in Glacier Bay National Park govern local climate and likely suppressed the climate signal due to their presence.

This finding agrees with results by other authors. Downscaling Community Climate System Model version 3.0 (CCSM3) data with a regional atmosphere-ocean climate model under consideration of the interaction ocean-atmosphere over cold ocean currents diminished an air-temperature increase in response to climate change as compared to neglecting ocean-atmosphere interaction, but considering future SSTs from CCSM3 [55].

Focusing on the domain over Glacier Bay (Figure 2), the mean $2 \mathrm{~m}$ temperature was similar between the CTL and SCE (Table 1) with differences about the accuracy in measurements [33]. Locally, the strongest temporal decreases were $0.4^{\circ} \mathrm{C}$, while the highest increase was $0.3^{\circ} \mathrm{C}$. The kurtosis of temperature differences was negative $(-0.7)$ indicating a much flatter distribution than a Gaussian distribution for the temperature difference. Changes in the kurtosis were also found in other studies on future regional climate [55].

Over the park's high-elevated glaciers, means of $2 \mathrm{~m}$ specific humidity remained below $5.6 \mathrm{~g} \cdot \mathrm{kg}^{-1}$ due to the general decrease of specific humidity with height (cf. Figure 1 and Figure 2). In SCE, mean $2 \mathrm{~m}$ specific humidity distribution showed broadly the same features as in CTL. However, in SCE, specific humidity notably increased over the archipelago with smaller increases in the North than South. Over Glacier Bay waters, mean specific humidity increased between less than $0.16 \mathrm{~g} \cdot \mathrm{kg}^{-1}$ and $0.24 \mathrm{~g} \cdot \mathrm{kg}^{-1}$. The increased water vapor and sensible heat in the lower ABL meant a destabilization in the lower atmosphere as compared to CTL. 


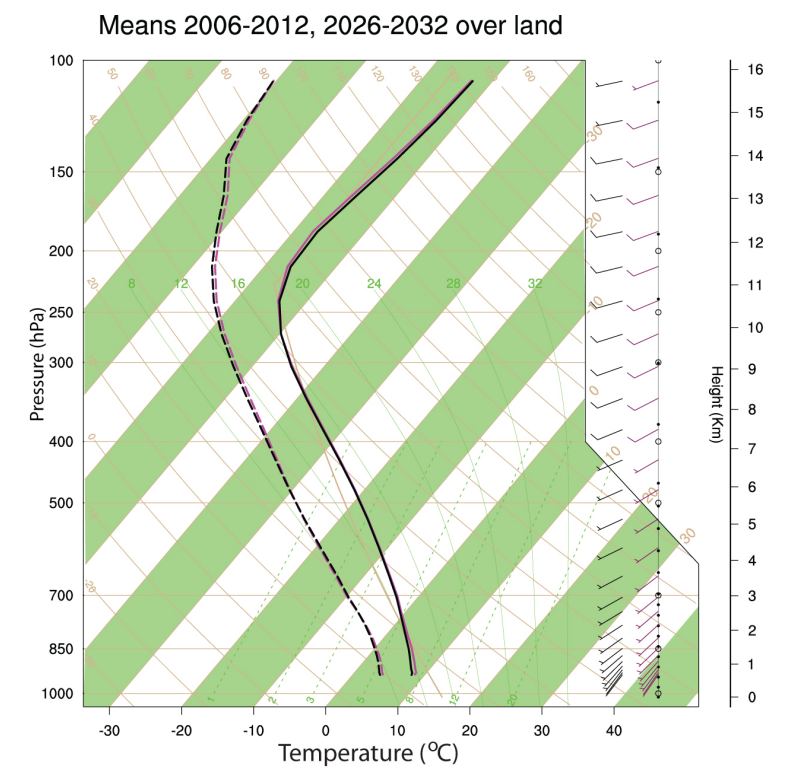

(a)

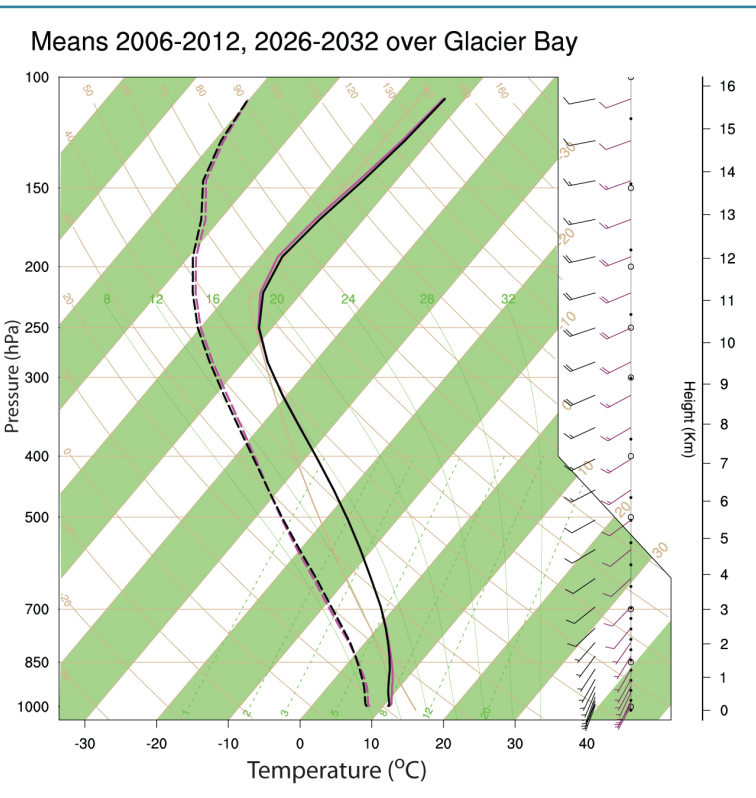

(b)

Figure 2. SkewT diagrams of mean vertical profiles of temperature (solid lines), dewpoint temperature (dashed lines), wind speed and direction (wind barbs) over the seasons over (a) land; and (b) Glacier Bay waters only as obtained from downscaling of CESM RCP4.5 simulations of 2006-2012 (CTL) given in black, and 2026-2032 (SCE) given in magenta.

Table 1. Statistics of the climatologies during the tourist season (May 15-September 15) as obtained from CTL and SCE for Glacier Bay and its adjacent areas shown in Figure 3. Here T, $q_{v}, v$ and RR are $2 \mathrm{~m}$ temperature, $2 \mathrm{~m}$ specific humidity, 10 $\mathrm{m}$ wind speed and season-accumulated precipitation. Note that skewness and kutosis are dimensionless.

\begin{tabular}{|c|c|c|c|c|c|c|c|c|}
\hline \multirow[t]{3}{*}{ Statistics } & \multicolumn{8}{|c|}{ Climatology statistics } \\
\hline & \multicolumn{2}{|c|}{$\mathrm{T}\left({ }^{\circ} \mathrm{C}\right)$} & \multicolumn{2}{|c|}{$\mathrm{q}_{\mathrm{v}}\left(\mathrm{g} \cdot \mathrm{kg}^{-1}\right)$} & \multicolumn{2}{|c|}{$\mathrm{v}\left(\mathrm{m} \cdot \mathrm{s}^{-1}\right)$} & \multicolumn{2}{|c|}{$\mathrm{RR}(\mathrm{mm})$} \\
\hline & CTL & SCE & CTL & SCE & CTL & SCE & CTL & SCE \\
\hline Mean & 7.5 & 7.4 & 6.24 & 6.40 & 5.15 & 4.92 & 425.0 & 402.2 \\
\hline StDev & 3.5 & 3.5 & 0.82 & 0.83 & 1.01 & 0.96 & 200.5 & 216.5 \\
\hline Skewness & -0.4 & -0.4 & -0.3 & -0.4 & 0.0 & 0.0 & 1.8 & 1.8 \\
\hline Kurtosis & -1.5 & -1.5 & -1.0 & -0.9 & -0.8 & -0.6 & 3.5 & 3.7 \\
\hline Minimum & -0.7 & -0.8 & 4.51 & 4.58 & 2.96 & 2.83 & 162.4 & 123.8 \\
\hline Maximum & 12.0 & 12.0 & 7.72 & 7.81 & 8.03 & 7.87 & 1323.6 & 1434.9 \\
\hline
\end{tabular}

Over the park, specific humidity increased with respect to its mean and internannual variability in SCE as compared to CTL (Table 1). The tail of negative deviations from the mean increased and flattened the humidity distribution indicating more variable humidity conditions over the season. Consequently, chemical reactions that involve water vapor and aerosol swelling change with implications for haze formation and visibility (cf. Section 3.4). Decreased (increased) specific humidity at about the same temperatures decreased (increased) the likelihood for fog and/or haze formation.

On average over the park, SCE-accumulated precipitation decreased $22.8 \mathrm{~mm}$ as compared to CTL (Table 1). However, the interannual variability increased and widened the low and high extremes of accumulated precipitation, ranging from local increases of up to $137.4 \mathrm{~mm}$ and decreases up to $104.5 \mathrm{~mm}$ (Table 1). The SCE-distribution of accumulated precipitation values around the mean flattened as compared to CTL. Together these findings suggest locally more severe drought and flood conditions in Glacier Bay in the near future. They also suggest that scavenging of trace gases and particulate matter will change in space and time.

Wind speed governs dispersion, as well as the ABL height and likelihood for inversions [57] [58]. Focusing 
on the park, mean $10 \mathrm{~m}$ wind speeds were highest over the glaciers because wind speed generally increased with height (cf. Figure 2). For example, average $10 \mathrm{~m}$ wind speeds increased over the St. Elias Mountains and in the northwestern part of the Gulf of Alaska (Figure 1), but decreased in the southeastern Gulf of Alaska and landwards. The altered wind-speed climatology resulted from shifts in the positioning of storms and was associated with changes in the North Pacific Index. Therefore, in the park, mean $10 \mathrm{~m}$ wind speed and interannual variability decreased by $0.23 \mathrm{~m} \cdot \mathrm{s}^{-1}$ and $0.05 \mathrm{~m} \cdot \mathrm{s}^{-1}$, respectively (Table 1). Across the grid cells over Glacier Bay and its adjacent area, there were more instances when $10 \mathrm{~m}$ wind speeds were below vs. above the mean. As compared to CTL, these less variable and calmer wind conditions in SCE increased the frequency of conditions favorable for mesoscale processes such as inversions, valley-mountain circulations, and slopewinds.

Recalling that the simulations assumed the same SSTs and glacier distribution, SCE mean vertical profiles of temperature, dewpoint temperature, and wind speed and direction over Glacier Bay followed those of CTL except for small, localized changes (cf. Figure 2). Above the ABL, SCE mean wind directions changed a couple of degrees as compared to CTL, while in the ABL such changes were marginal to non-existent, as the terrain governed the wind direction on average. Due to climate change, the lower ABL was warmer and wetter with calmer winds while the upper ABL was drier (Figure 2), although mean temperatures remained about the same. Isothermal to inversion conditions continued to dominate in Glacier Bay, and terrain features governed the mean conditions because local surface forcing predominates during calm wind conditions [12] [33].

\subsection{Inversions}

Figure 3 shows the spatial distribution of inversions in the fjord. In CTL, under surface-inversion conditions over Glacier Bay, the mean vertical temperature gradients varied from greater than $4^{\circ} \mathrm{C} \mathrm{km}^{-1}$ to less than $7^{\circ} \mathrm{C}$ $\mathrm{km}^{-1}$. The general distribution of surface-inversion heights over Glacier Bay was similar in the CTL and SCE, but with reduced spatial variability and decreased surface-inversion heights. The spatial variability in mean vertical temperature gradient increased in SCE. In SCE, inversion strengths ranged from greater than $2^{\circ} \mathrm{C} \mathrm{km}^{-1}$ to more than $11^{\circ} \mathrm{C} \mathrm{km}^{-1}$ representing a strong change in the extremes, with half as strong and nearly twice as strong inversion strengths as in CTL.

In SCE, inversion height decreased significantly by $29 \mathrm{~m}$ on temporal and spatial average over Glacier Bay to $234 \mathrm{~m}$. Similarly, significant decreases in SCE ranged from $23 \mathrm{~m}$ to $36 \mathrm{~m}$ locally (Figure 3(a) and Figure 3(b)). In SCE, interannual variability decreased by $45 \%$ to $\pm 38 \mathrm{~m}$. This means that spatial decreases were in the range of interannual variability. Both decreased inversion height and decreased interannual variability increase the likelihood of pollutant accumulation in the same levels.

On average over the seasons and Glacier Bay, inversion strength increased significantly from $9.1^{\circ} \mathrm{C} 100 \mathrm{~m}^{-1}$

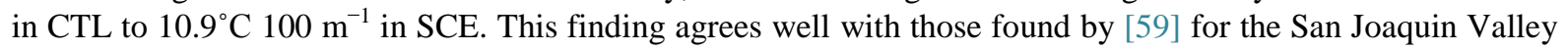
in response to climate change under stagnant conditions. On average over Glacier Bay, the interannual variabil-

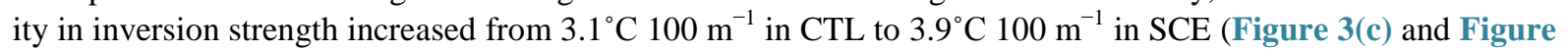
$3(d)$ ). Furthermore, the diurnal variability in strength and total strength of inversions increased (Figure 4(c) and Figure 4(d)).

In CTL and SCE, surface-inversion heights showed a diurnal course until the end of summer (Figure 4(a) and Figure 4(b)). The dynamics of inversion heights in the SCE mirrored those of CTL with low and high inversion heights until mid-August. On average, though, future inversion heights were reduced. For the remaining season, inversion heights decreased in CTL and became random due to the more frequent stroms as the season progressed, while the SCE inversion heights often coincided with the ABL height.

In the future, pollutants are more likely to be trapped by inversions and be closer to the water in Glacier Bay although the duration of inversions is anticipated to decrease on average by $4.5 \mathrm{~h}$ (from $\sim 23.5 \mathrm{~h}$ to $\sim 19 \mathrm{~h}$ ). In some locations, inversions lasted $2 \mathrm{~h}$ to $9 \mathrm{~h}$ less in SCE than in CTL. Consequently, time for pollutant accumulation decreased. Since interannual variability of inversion duration decreased from about $12 \mathrm{~h}$ to $5 \mathrm{~h}$, seasons became more alike in SCE.

In SCE, inversion frequency increased, while its interannual varibility decreased. The absolute increase of inversion frequency varied over Glacier Bay, but amounted to about a $4 \%$ increase on average (not shown). The increased water vapor and sensible heat in the near-surface ABL of Glacier Bay due to climate change caused the reduced duration of inversions, while the reduced wind speed increased the frequency of inversion formation. Increased inversion frequency in response to climate change was also found for the San Joaquin Valley [59]. 


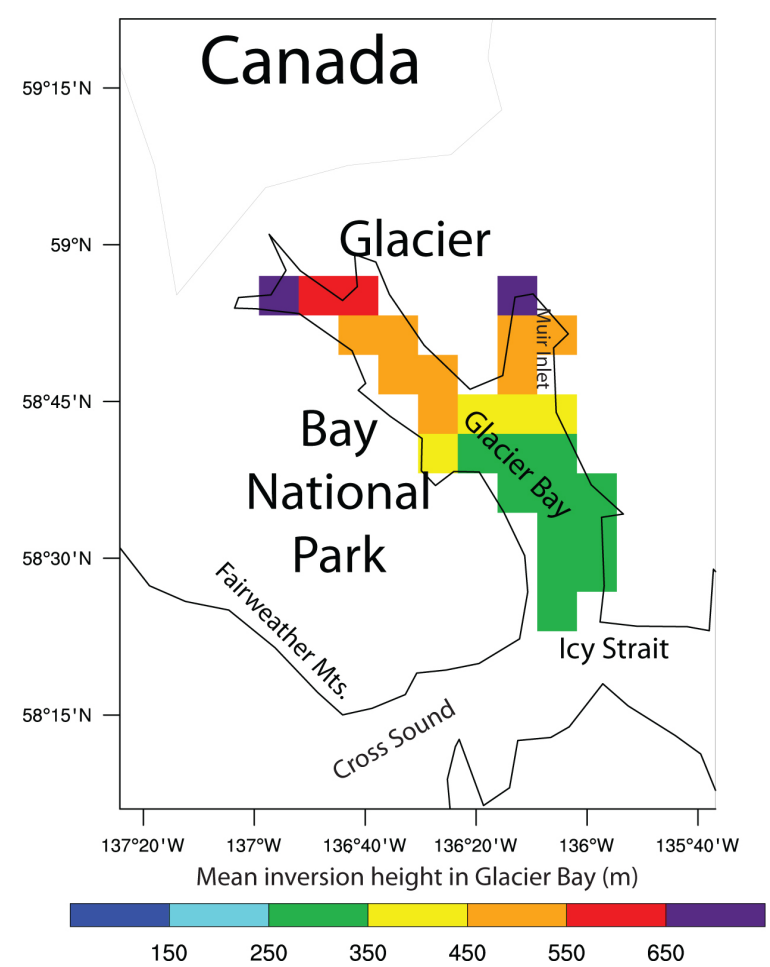

(a)

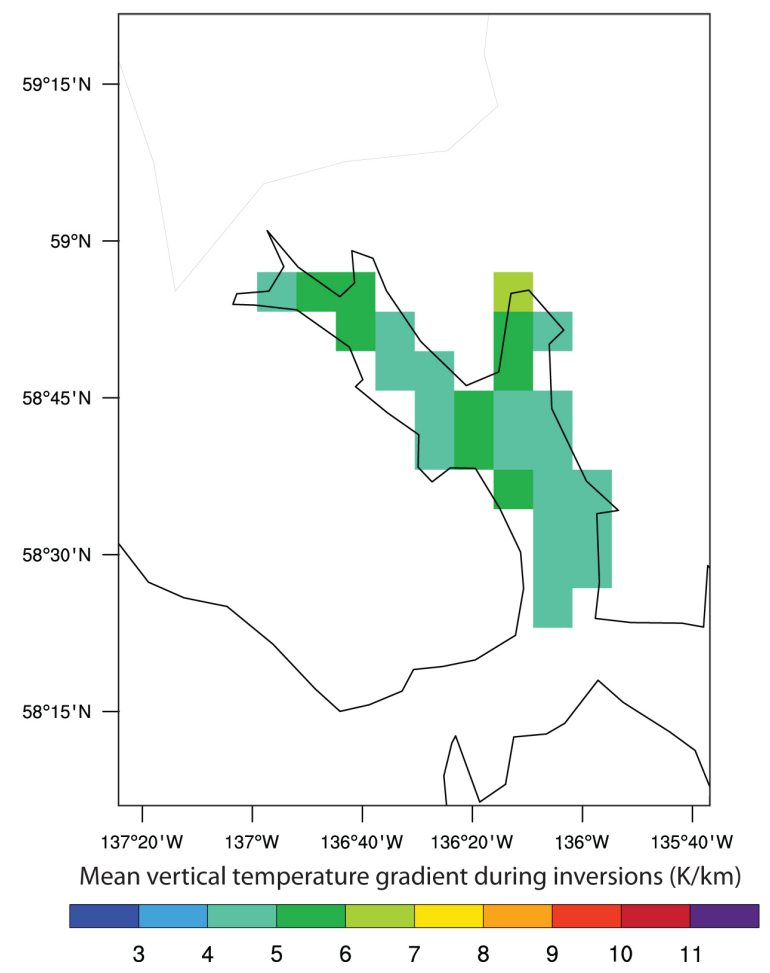

(c)

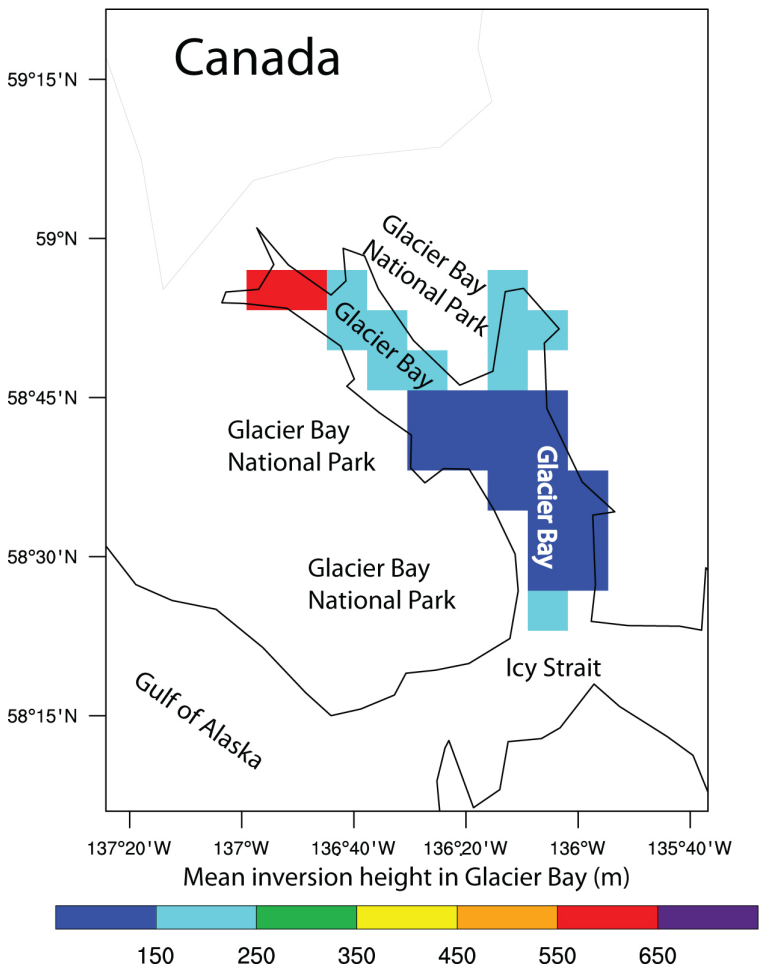

(b)

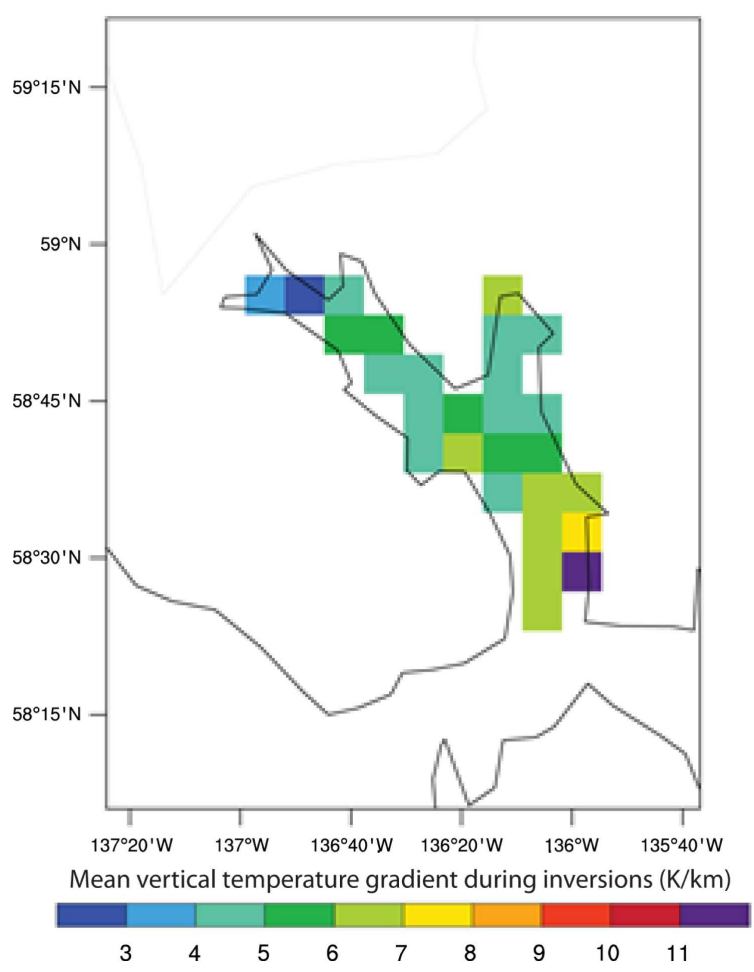

(d)

Figure 3. Spatial distribution of mean ((a), (b)) inversion height and ((c), (d)) vertical temperature gradient over Glacier Bay as obtained from downscaling of CESM RCP4.5 simulations of ((a), (c)) 2006-2012 (CTL) and ((b), (d)) 2026-2032 (SCE). 


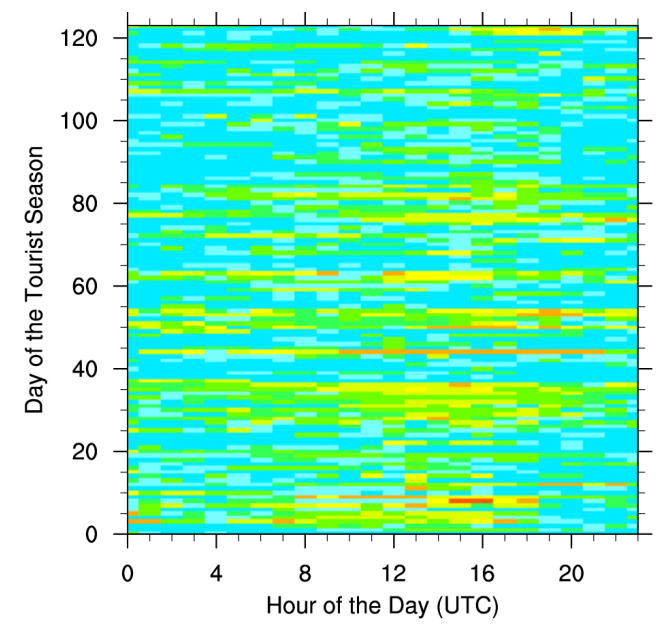

(a)

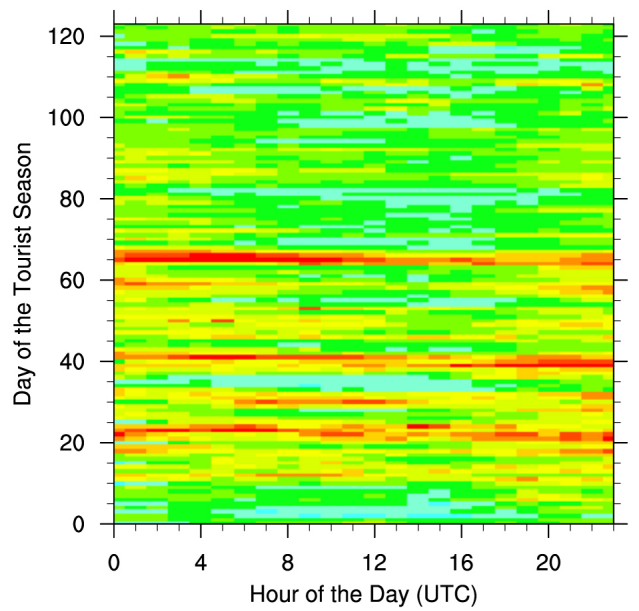

(c)

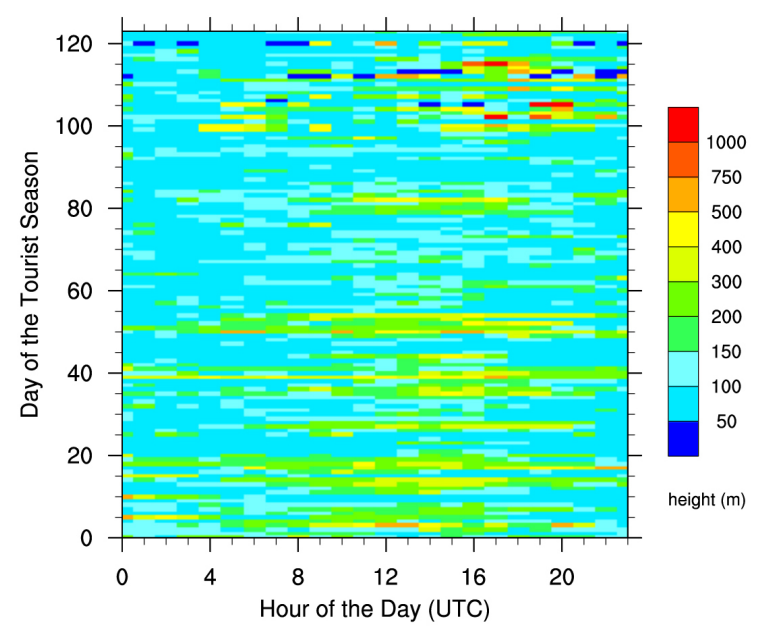

(b)

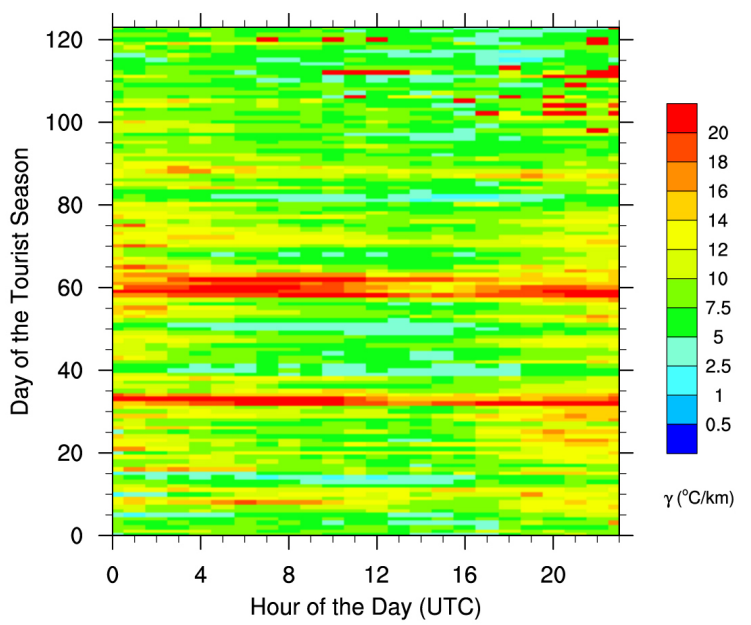

(d)

Figure 4. Temporal evolution of the diurnal course of mean ((a), (b)) inversion height and ((c), (d)) vertical temperature gradient averaged over all inversions occurring anywhere over Glacier Bay waters as obtained from downscaling of CESM RCP4.5 simulations of ((a), (c)) 2006-2012 (CTL) and ((b), (d)) 2026-2032 (SCE). Time is given with respect to UTC. Alaska Standard Time is UTC $-9 \mathrm{~h}$.

In sum, our model results are consistent with an atmosphere over Glacier Bay that becomes more stable more often due to decreased wind speed. However, the on-average enhanced sensible heat and water-vapor fluxes, as well as wind shear, contributed to the dissipation of inversions more quickly following formation. Since calm winds are favorable for inversion formation, inversions rebuilt more frequently after breaking down.

\subsection{Precursor Gases and Particulate Matter}

Chemical reactions are expected to occur more readily in the future due to the warmer average ABL conditions than current (Figure 2). Concentrations at ship level also will change due to the increased frequency of inversion dissipation, which means enhanced vertical mixing. The wetter conditions anticipated for the future will cause changes in wet and dry deposition and sedimentation of particulate matter. Due to shifts in wind speed, wind direction (Figure 1) and pressure distribution, large differences in concentrations also occurred over the Gulf of Alaska (not shown). In the fjords and along the coast where inversions often formed, trace gas and particulate matter concentrations differed less than where concentrations where high due to ship emissions. These findings suggest that local features and/or mesoscale processes may diminish the role of climate warming in altering climatologies and entrapment and retention of precursor gases and particulate matter. In general, pollutant 
concentrations aerosols and soluble gases in Glacier Bay changed due to the altered amount, and distribution of precipitation. During precipitation events, concentrations decrease meaning that both increased and decreased precipitation contributed to concentration changes.

In the park, season-mean concentrations and interannual variability of $\mathrm{SO}_{2}$ decreased neglibly in response to climate change, despite decreased volume for pollutant accumulation. The reduced duration of inversions, and hence reduced time for pollutant accumulation underneath inversions, contributed to this decrease. The increased frequency of inversion breakups permitted vertical mixing during these events, which diluted the pollution and reduced the concentrations. Another reason for reduced $\mathrm{SO}_{2}$ concentrations is that oxidation rates to form sulfate increase with increasing temperature. Locally and temporily decreases in sulfate occurred associated with increases in wet deposition in areas of increased precipitation. Increases in sulfate occurred in areas of increased $\mathrm{SO}_{2}$ oxidation and/or decreased precipitation. Similar responses to climate change were found for the US Northeast in other studies [60].

On average over the park and season, $\mathrm{NO}_{2}$ concentrations marginally increased $(0.05 \mathrm{ppb})$ due to climate change (Figure 5(a) and Figure 5(d)). As temperatures go up, soil NO emissions increase exponentially [61]. Furthermore, less $\mathrm{NO}_{2}$ was tied up in peroxyacylnitrates (PAN) as temperatures increase.

If pollutant tranport, macroscopic mixing, and precipitation changes were the only processes to affect concentrations, all species should increase/decrease concurrently in the same location. However, our results (e.g. Figure 5(d) and Figure 5(e)) illustrated that the actual behavior differed from this scenario. For example, seasonmean $\mathrm{NO}_{\mathrm{x}}$ concentrations decreased in the upper bay, while season-mean $\mathrm{PM}_{10}$ concentration decreased over the entire bay, and $\mathrm{SO}_{2}$ remained around contemporary levels with neglible overall decrease (not shown).

This different behavior was due largely to processes working in different directions on the chemical fate of the species. While both $\mathrm{SO}_{2}$ and $\mathrm{NO}_{\mathrm{x}}$ are precursor gases for particle formation, their reaction paths and temperature-dependent Henry and reaction-rate coefficients differ [62]. Sulfate formation is a primary sink for $\mathrm{SO}_{2}$ while nirate formation competes with ozone chemistry among other processes. Consequently, the temperature changes (Figure 1(a) and Figure 1(b)) modified $\mathrm{SO}_{2}$ and $\mathrm{NO}_{\mathrm{x}}$ distributions differently when it came to chemical processes. Furthermore, as aforementioned, PAN is a reservoir for $\mathrm{NO}_{2}$ at low temperatures. When reactive radicals and water vapor are present, $\mathrm{SO}_{2}$ can oxidatize to sulfuric acid $\left(\mathrm{H}_{2} \mathrm{SO}_{4}\right)$ that has a very low vapor pressure. Ammonia $\left(\mathrm{NH}_{3}\right)$ may further neutralize the sulfate-related aerosol acidity to form ammonium sulfate aerosol $\left(\left(\mathrm{NH}_{4}\right)_{2} \mathrm{SO}_{4}\right)$ [10] [63]. This process competes with neutralization of nitric acid $\left(\mathrm{HNO}_{3}\right)$ by $\mathrm{NH}_{3}$ to produce ammonium nitrate aerosol $\left(\mathrm{NH}_{4} \mathrm{NO}_{3}\right)$. Nitric acid stems from oxidization of $\mathrm{NO}_{\mathrm{x}}$. Sulfate aerosols can dissolve and act as cloud-condensation nuclei [10] [64].

In addition, dry deposition rates of $\mathrm{SO}_{2}$ and $\mathrm{NO}_{\mathrm{x}}$ depend, among other things, on temperature and humidity, and differ for the two species [44]. As aforementioned, some soil bacteria emit $\mathrm{NO}_{\mathrm{x}}$ where this activity depends on soil-moisture and temperature conditions [48] [61]. Thus, locally biogenic $\mathrm{NO}_{\mathrm{x}}$ emissions compensated or exceeded $\mathrm{NO}_{\mathrm{x}}$ deposition. Consequently, $\mathrm{NO}_{\mathrm{x}}$ increased locally where $\mathrm{SO}_{2}$ decreased. The sensitivity of the biogenic emissions to the local soil temperature and moisture conditions meant that dry deposition of $\mathrm{NO}_{\mathrm{x}}$ occurred in CTL, while $\mathrm{NO}_{\mathrm{x}}$ emission occurred in SCE and vice versa. Changes in biogenic emissions of VOCs affected $\mathrm{NO}_{\mathrm{x}}$ as well because both are involved in ozone and PAN chemistry [10]. The different chemical (reactions, dissociation) and physical fates (deposition, dissociation, wash- and rainout) of $\mathrm{SO}_{2}$ and $\mathrm{NO}_{\mathrm{x}}$ explain why decreases/increases of these precursor gases occurred in different places.

Nevertheless, overall, in Glacier Bay, daily mean $\mathrm{SO}_{2}$ and $\mathrm{NO}_{\mathrm{x}}$ concentrations were more sensitive to the cruise-ship emissions than climate change. Concentrations of $\mathrm{O}_{3}$ decreased within the range of current measurement accuracy $(0.1 \mathrm{ppb})$.

We note that the lower inversion heights in SCE (Figure 3(a) and Figure 3(b), Figure 4(a) and Figure 4(b)) did not necessarily equate to increased concentrations at ship height compared to CTL (Figure 5) because inversion duration decreased. At similar rates of cruise-ship emissions, reduced inversion duration would result in lower concentrations as the emitted species occupy the same volume, while all other sinks and sources remain the same. On the contrary, a lower inversion height with all other factors remaining the same would mean increased concentrations as compared to CTL.

Together these findings suggest a shift in the partitioning of the contributions of $\mathrm{SO}_{2}$ and $\mathrm{NO}_{\mathrm{x}}$ in the aerosol formation and aerosol-growth processes in response to climate change. Given that the current National Ambient Air Quality Standards for $\mathrm{SO}_{2}$ and $\mathrm{NO}_{\mathrm{x}}$ are $75 \mathrm{ppb}$ and $100 \mathrm{ppb}$, the responses of these species to climate change are neglegible. Likewise, mean $\mathrm{PM}_{10}$ concentrations along the major cruise path increased by less than $1 \mu \mathrm{g} \cdot \mathrm{m}^{-3}$ 


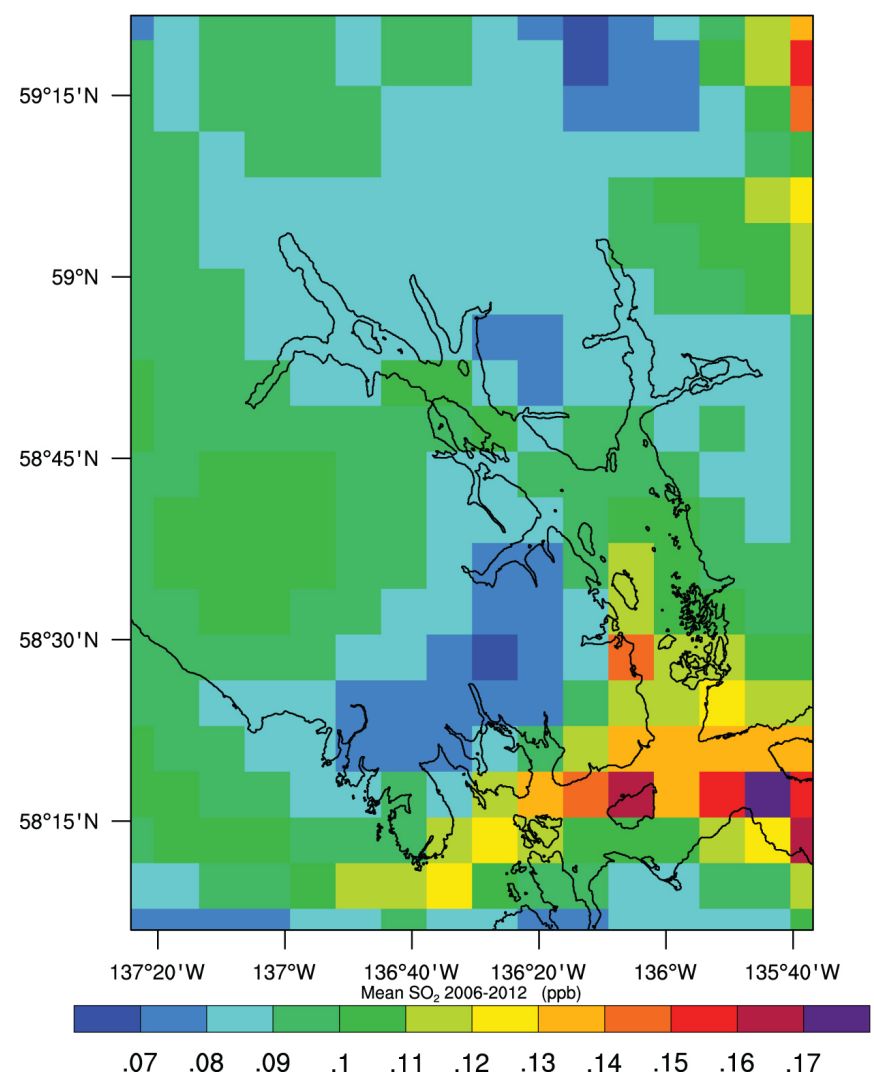

(a)

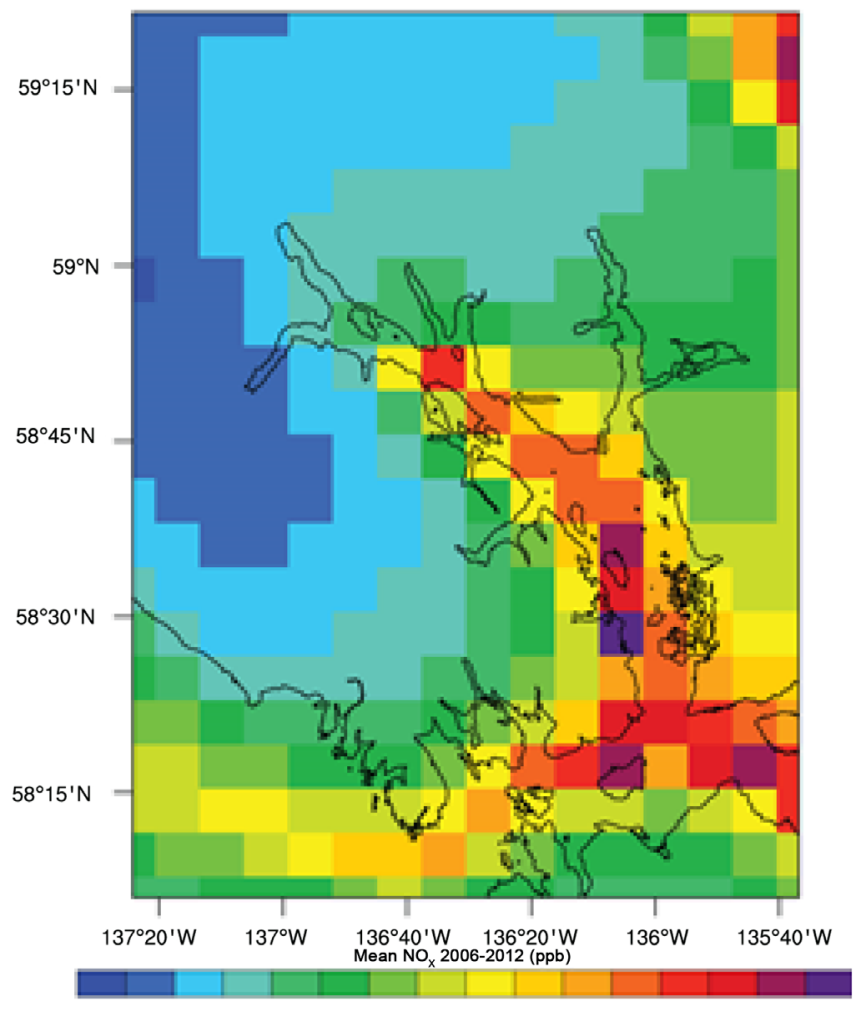

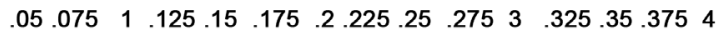

(b) 


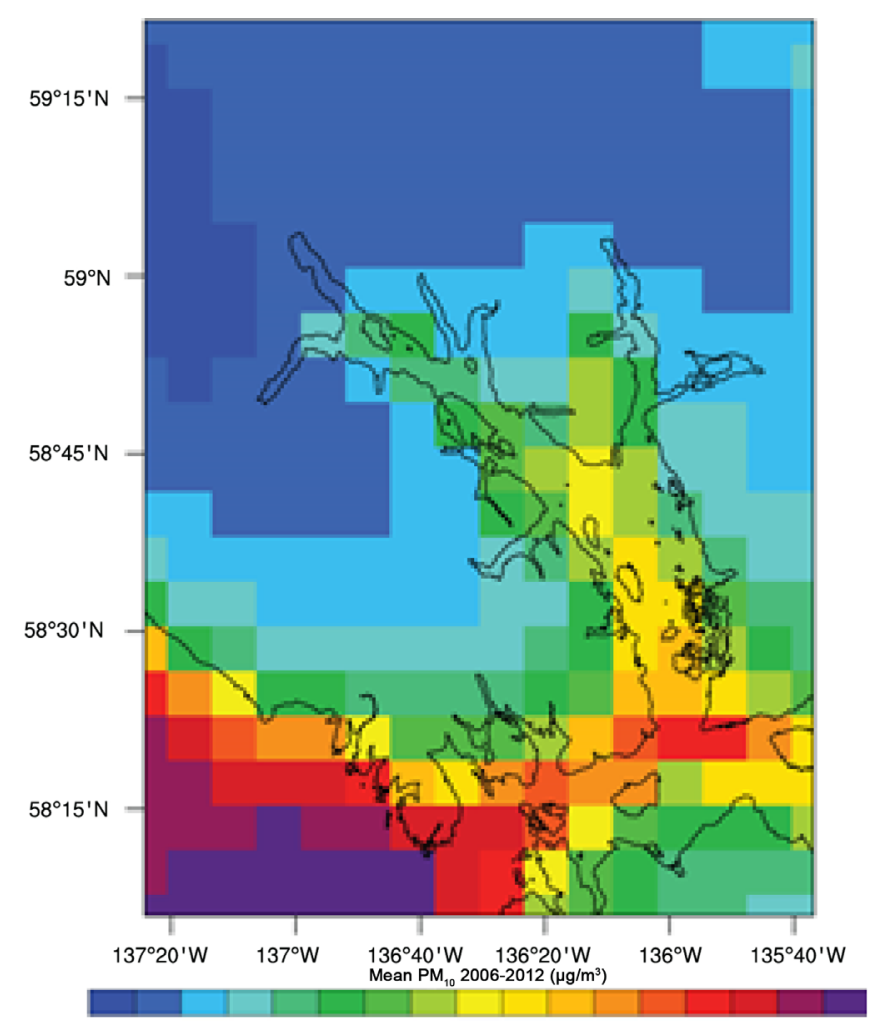

$\begin{array}{llllllllllllllll}1 & 1.5 & 2 & 2.5 & 3 & 3.5 & 4 & 4.5 & 5 & 5.5 & 6 & 6.5 & 7 & 7.5 & 8 & 8.5\end{array}$

(c)

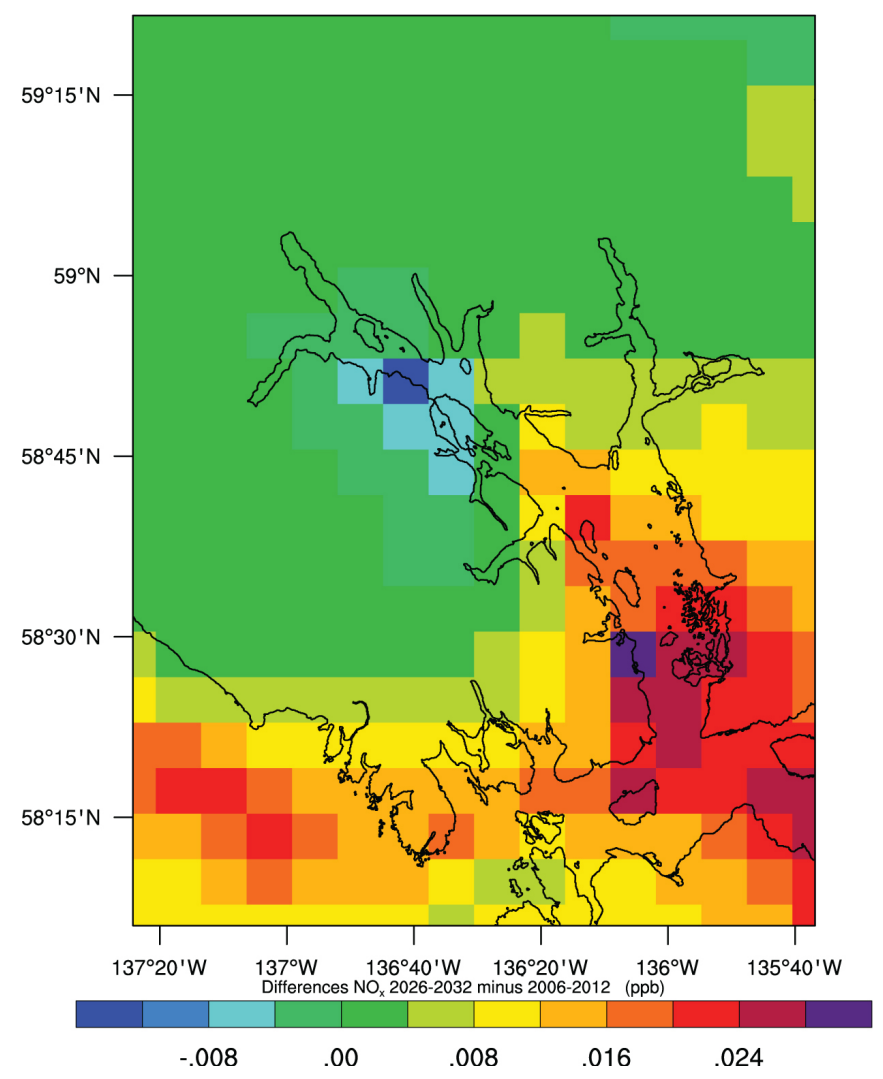

(d) 


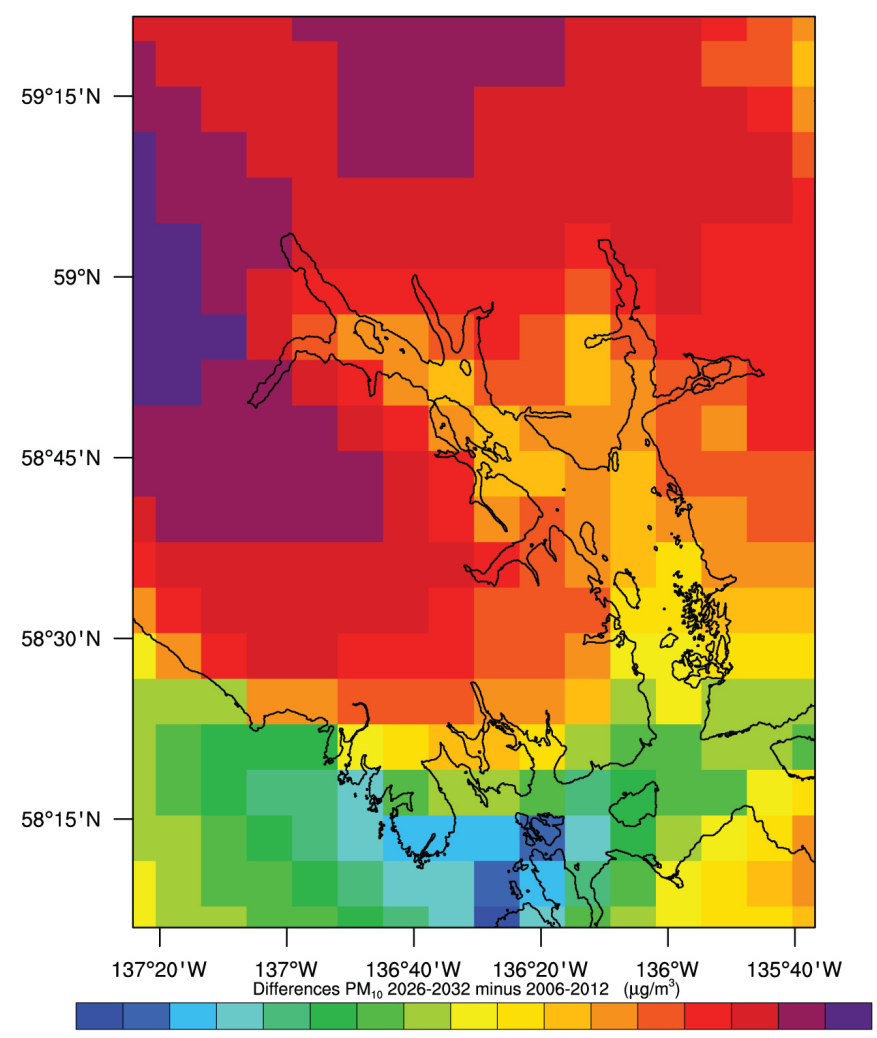

$-.9-.85-.8-.75-.7-.65-.6-.55-.5-.45-.4-.35-.3-.25-.2-.15$

(e)

Figure 5. Zoom-in on the spatial distribution of mean season concentration over Glacier Bay National Park at ship height as obtained from downscaling of CESM RCP4.5 simulations for (a) $\mathrm{SO}_{2}$; (b) $\mathrm{NO}_{x}$; and (c) $\mathrm{PM}_{10}$ and differences 2026-2032 minus 2006-2012 of (d) $\mathrm{NO}_{\mathrm{x}}$, and (e) $\mathrm{PM}_{10}$. Note that differences for $\mathrm{SO}_{2}$ were typically about $1 \mathrm{ppt}$ (therefore not shown).

with only slight increases of about $0.2 \mu \mathrm{g} \cdot \mathrm{m}^{-3}$ or more occurring elsewhere in Glacier Bay towards the end of the season (not shown). These finding agree with climate-change induced differences in model-simulated annual average PM concentrations between the presence and the 2050s [16].

These marginal changes result due to competing changes in individual aerosol species. However, as indicated earlier, means may not be a good metric for assessing management relevant impacts of climate change on PM, i.e. episode analysis may be a better tool. Besides the concentrations of $\mathrm{NO}_{2}$, the $\mathrm{PM}_{10}$ concentrations along the cruise-ship route in Glacier Bay are relevant for visibility because once critical humidity values are exceeded, particulate matter swells and increases the mass of $\mathrm{PM}_{10}$ [10] [11] [65]. On a daily basis, the highest $\mathrm{PM}_{10}$ concentration means occurred during cruise-ship visits. Seasonally, in both CTL and SCE, column-integrated means of $\mathrm{PM}_{10}$ over Glacier Bay showed distinct episodes of low and elevated values until the end of August, with the highest values towards the end of the season (Figure 6(a) and Figure 6(b)) when more cyclones moved into the park. Future increases in relative humidity caused the increase seen at the end of the season.

In the park at ship height, the season-mean concentrations and interannual variability of $\mathrm{PM}_{10}$ is expected to marginally decrease (Figure 5(c)) and remain about the same, respectively. While aerosol formation by gas-toparticle conversion decreases with increasing temperature, wetter conditions lead to swelling of existing particulate matter. Thus, locally and temporally marginal increases and decreases in concentrations occurred (Figure 5(c) and Figure 6). The wetter conditions resulted in a greater number of grid cells with $\mathrm{PM}_{10}$ concentrations occurring above the mean towards the end of the season. The compensating lower $\mathrm{PM}_{10}$ concentrations resulted from changes in sedimentation and wet deposition. Sedimentation removes large particles faster than small particles.

Figure 4 and Figure 6 indicate that the Glacier Bay mean climatologies of high column-integrated $\mathrm{PM}_{10}$ and strong inversions matched up only occassionally (e.g. around day 90 in CTL, day 10 in SCE). The same was true 
2006-2012 Mean column integrated $\mathrm{PM}_{10}$ over Glacier Bay

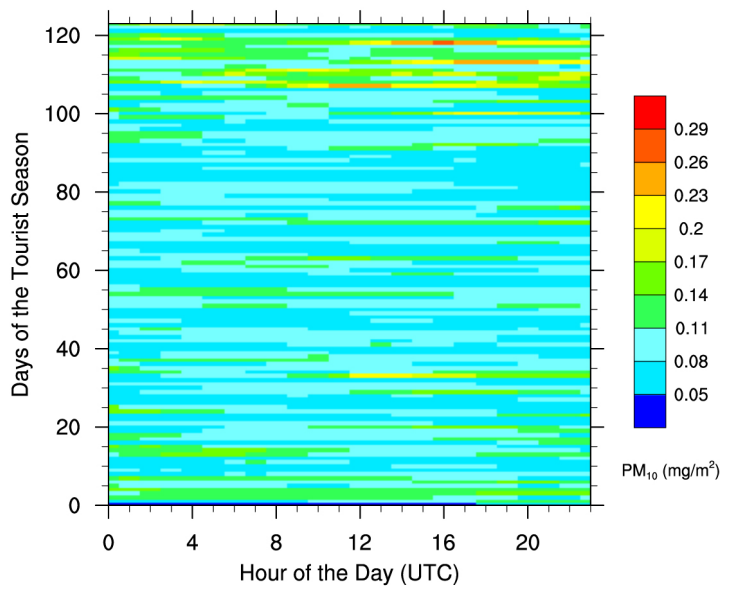

(a)
2026-2032 Mean column integrated $\mathrm{PM}_{10}$ over Glacier Bay

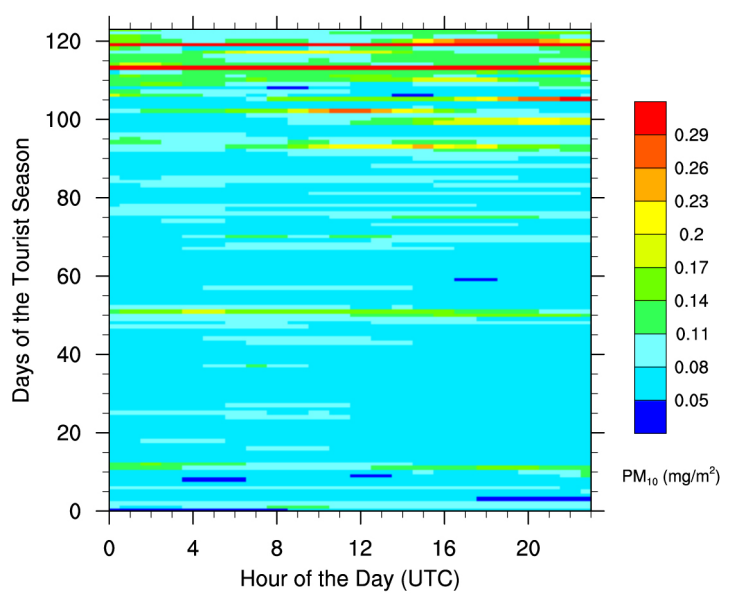

(b)

Figure 6. Temporal evolution of the diurnal course of tourist-season mean column integrated $\mathrm{PM}_{10}$ as obtained from downscaling of CESM RCP4.5 simulations of (a) 2006-2012 (CTL) and (b) 2026-2032 (SCE) averaged over Glacier Bay. Time is given with respect to UTC. Alaska Standard Time is UTC $-9 \mathrm{~h}$.

for low surface-inversion height and $\mathrm{PM}_{10}$. These features were partly due to the temporal variability of cruiseship emissions during their visits, concentrations at onset of accumulation, duration of pollutant accumulation, and number of inversions occurring within the column. We found that often multiple inversions existed. Thus, pollutants accumulated at different heights in CTL and SCE.

In SCE, lower column-integrated $\mathrm{PM}_{10}$ values occurred at onset and most of the tourist season than in CTL, but higher values occurred towards the end of the summer (Figure 6). Similar to CTL, the PM 10 $_{10}$ concentrations were not a function of surface-inversion height and strength alone (cf. Figure 4 and Figure 6).

The column integrated $\mathrm{PM}_{10}$ is expected to go down (Figure 6) for various reasons. The calming of winds increased removal of large particles by sedimatation. However, it had an additional effect in that it reduced horizontal mixing and transport of pollutants into and out of Glacier Bay. The changes in the positioning of the major high and low-pressure systems also altered mean wind direction (Figure 1(e) and Figure 1(f)). Consequently, advection changed and modified the distributions of concentration climatologies. Note that changes in transport and non-molecular mixing processes affected all species similarly.

Changes in biogenic VOC emissions due to climate change may affect PM concentrations. While the representation of biogenic emissions [48] used in our study considers the link between increased temperature and increased VOC emissions, substantial uncertainty remains as ambient $\mathrm{CO}_{2}$ concentrations may affect isoprene emissions in a nonlinear way [60]. How climate change will affect biogenic VOC emissions, such as $\alpha$-pinene and $\beta$-pinenes, is still subject to research. Recent advances in understanding of isoprene oxidation in the aqueous phase have not yet made their way into air-quality models. However, they suggest that the role of isoprene in forming aerosols may be underestimated in these models [60]. Research on the impacts of increasing temperatures on the emissions of nonisoprene VOCs is sparse as well [60].

\subsection{Visibility}

Visibility depends on relative humidity, and the concentrations of particulate matter and $\mathrm{NO}_{2}$ in the atmosphere [53]. The haze index gives the relationship between changes in light extinction, $b_{\text {ext }}$ and perceived visibility. The haze index (in deciview) is defined as $H I=10 \cdot \ln \left(0.1 \cdot b_{\text {ext }}\right)$. The light extinction $b_{\text {ext }}$ is a function of relative humidity, and the concentrations of sulfate, nitrate, organic carbon, elemental carbon, fine soil particles with aerodynamic diameters less than $2.5 \mu \mathrm{m}$, coarse particulate matter with aerodynamic diameters less than $10 \mu \mathrm{m}$ and greater than $2.5 \mu \mathrm{m}$, and the light scattering due to Rayleigh scattering. The latter depends on the $\mathrm{NO}_{2}$ concentration [53].

The light extinction was calculated from the WRF/Chem results (for method see [33]) using the fine soil data from Petersburg as a proxi for Glacier Bay. For these results, low haze-index values equate to high visibility. 
Typically, visibility is determined at $1.8 \mathrm{~km}$ height [53]. However, since the park visitors are onboard cruiseships, we calculated $H I$ at ship height to assess potential changes in visitor experience.

In CTL and SCE, high relative humidity was the main cause of low visibility. At ship height, on average over Glacier Bay and the seasons, mean HI was $3.7 \mathrm{dv}$ in both CTL and SCE. This visibility is better than the 2018 target [53] set by the US Environmental Protection Agency (EPA) for pristine areas. Clouds often occurred at the top of the ABL, which blocked the view to or at $1.8 \mathrm{~km}$ height.

In Glacier Bay, mean haze indices at ship height ranged between $2 \mathrm{dv}$ and $4 \mathrm{dv}$ for CTL, except at the entrance of the fjord and in the Tarr and upper Muir Inlets (Figure 7). In these locations, mean $\mathrm{HI}$-values were less than $5 \mathrm{dv}$ and $6 \mathrm{dv}$, respectively, due to emissions from vessels cruising thru Ice Strait in the former, and bethering in front of the glaciers in the latter case. The lowest mean haze indices ( $2 \mathrm{dv} \leq H I<3 \mathrm{dv}$ ) occurred in areas of the park where the NPS prohibits cruise ship traffic.

In SCE, visibility generally degraded over the mid section of the bay. The reduced and less variable wind speeds anticipated for the future favored local mesoscale processes and the more frequent formation of inversions (Figure 3 and Figure 4) that hinder vertical mixing while present. While climate change is expected to decrease the duration of inversions, thereby reducing the time of pollutant build-up, concomitant decreases in mean surface-inversion heights resulted in smaller volumes where primary and secondary pollutants accumulated. Consequently, locally (Figure 5(b) and Figure 5(c)) and temporally (Figure 6(a) and Figure 6(b), Figure 8(b) and Figure 8(c)) $\mathrm{NO}_{2}$ and $\mathrm{PM}_{10}$ concentrations increased despite the same amount of those pollutants emitted from ships.

The altered amount and distribution of precipitation also modified aerosol- and soluble gas removal with implications for visibility. In areas with more and/or more frequent precipitation, visibility-reducing pollutants decreased in SCE, despite the same amount of emissions and increased humidity. On the contrary, in areas with less and/or less frequent precipitations, pollutants built up over time, particularly under calm wind conditions. In these areas, visibility climatology shifted towards increased $H I$ values.

The temporal and local extremes of hourly $\mathrm{HI}$ in Glacier Bay were $1.6 \mathrm{dv}$ and $7.9 \mathrm{dv}$ for CTL. While the lowest value, i.e. best visibility remained the same, the upper $H I$ improved to $7.3 \mathrm{dv}$ in SCE. This means that the

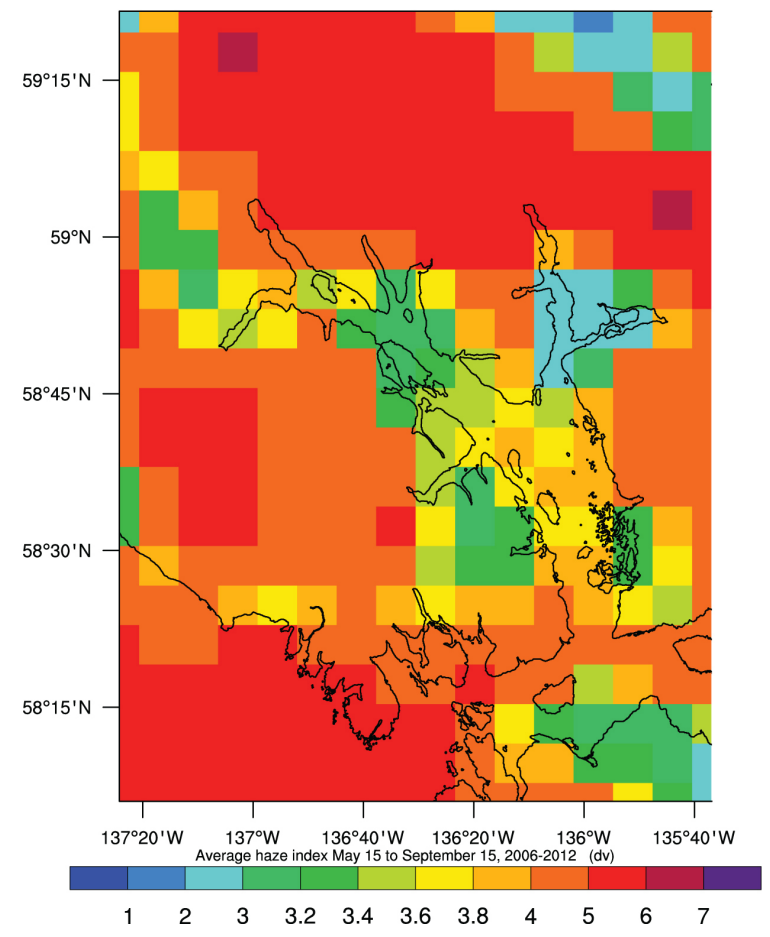

(a)

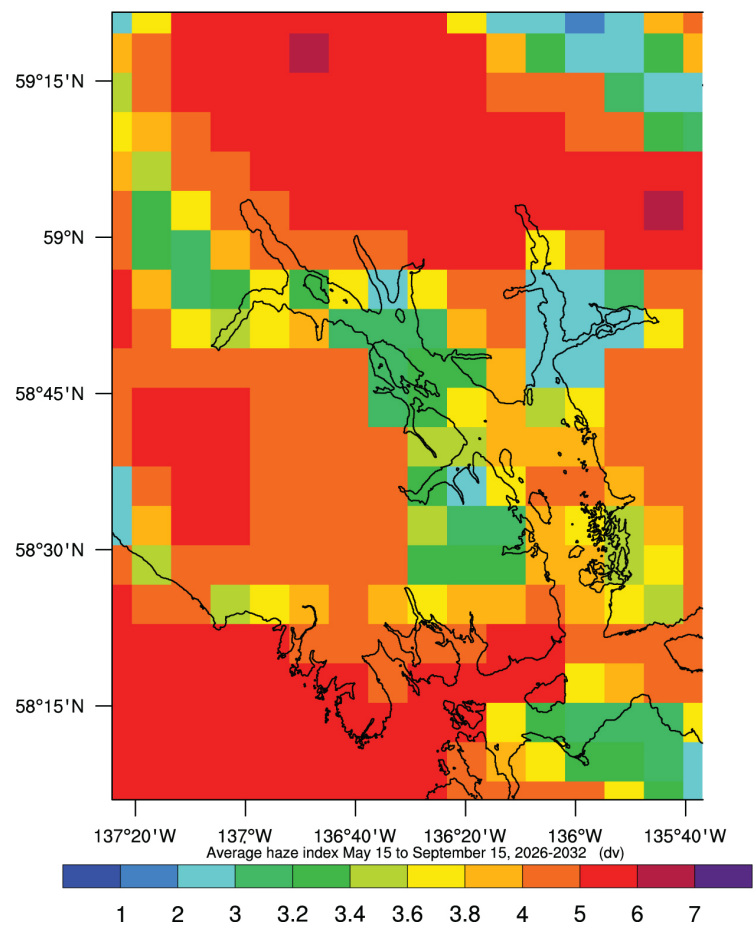

(b)

Figure 7. Tourist-season mean haze indices in the park as obtained from downscaling of CESM RCP4.5 simulations of (a) 2006-2012 (CTL) and (b) 2026-2032 (SCE). 


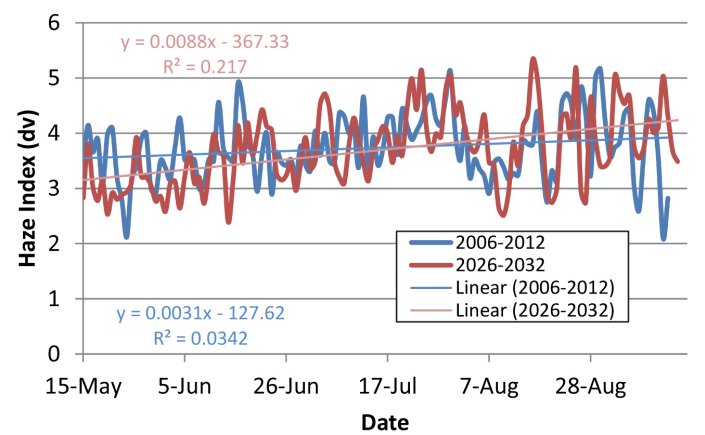

(a)

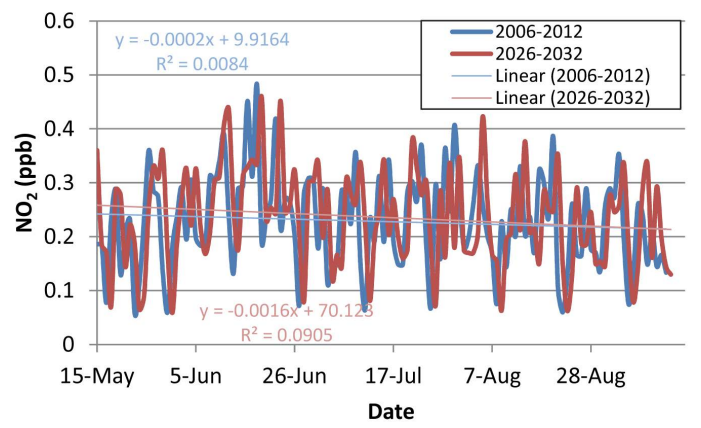

(c)

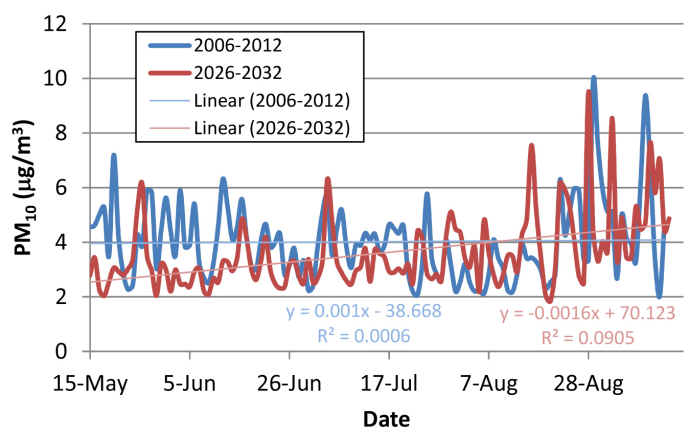

(b)

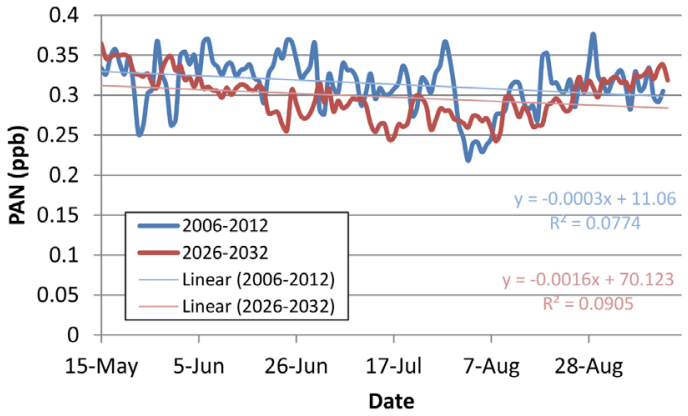

(d)

Figure 8. Mean temporal evolution of (a) haze index, and concentrations of (b) $\mathrm{PM}_{10}$; (c) $\mathrm{NO}_{2}$, and (d) PAN averaged over all grid-cells over Glacier Bay waters at ship height as obtained from downscaling of CESM RCP4.5 simulations (bold lines) of 2006-2012 (CTL) and 2026-2032 (SCE) and linear trends (thin lines). Equations and $\mathrm{R}^{2}$ values for the trends are given in blue and red for CTL, and SCE, respectively.

worst days of visibility in contemporary conditions will not be as bad in the future. We note, however, that even these maximum values still represent visibility standards that outperform the US EPA [53] 2018 target of 25.1 $\mathrm{dv}$ for pristine areas.

To examine the temporal evolution over the season we calculated a linear trendline to eliminate variability within the season that stems from synoptic scale weather pattern. Doing so provides an easy mean to assess trends and changes between CTL and SCE. In both CTL and SCE, the mean HI degraded slightly as the season progressed and more cyclones reached Glacier Bay (Figure 8). Early in the season, visibility was better in SCE than in CTL, while the opposite was true later. However, at the beginning of the season, visibility in CTL was still better than visibility in SCE at the end of the season. This means that despite local improvements and initially improved conditions, the overall visibility conditions are anticipated to degrade in the future.

The changes in visibility were strongly related to the response of $\mathrm{PM}$ and $\mathrm{NO}_{2}$ to climate change (Figures 8(a)-(c)). Warmer conditions mean less gas-to-particle formation. Calmer conditions mean enhanced removal of coarse particle by sedimentation. Thus, PM concentrations were lower at the beginning of the season in SCE than CTL. The wetter conditions in SCE permitted swelling earlier on available PM than in CTL. Thus, at the end of the season, PM concentrations tended to increase as compared to CTL (Figure 5, Figure 6 and Figure 8(b)). At high relative humidity namely, soluble nitrates and sulfates swell and contribute to reduced extinction [53].

Further-reducing visibility at ship heights (Figure 7) were projected warmer than average conditions (Figure 1 and Figure 2). The warmer conditions meant less $\mathrm{NO}_{2}$ was stored as PAN, which led to increases of the $\mathrm{NO}_{2}$ concentrations (Figure 8(a), Figure 8(c) and Figure 8(d)) that degrade visibility [53].

The balance between processes that diminish or enhance pollutant concentrations became most obvious when looking at the trends in visibility and visibility relevant concentrations in Glacier Bay (Figure 8). For both CTL and SCE, the atmosphere at the beginning of the season is, on average, drier and the SSTs and air temperatures are lower compared to later in the season beginning mid-August. Thus, on average, atmospheric chemistry was slower earlier in the season whereas mean humidity permitted aerosol growth during the latter part of the season. 
Under conditions of climate change, the ABL at the beginning of the season, even though warmer and wetter, was still drier and cooler than later in the season. However, the warmer and wetter conditions at the beginning meant less primary pollutant accumulation due to decreased inversion duration (Figure 4 and Figure 6) and faster reactions than under contemporary climate, as conditions were still not wet enough for enhanced swelling of particles. Despite warmer conditions, it was still too cold for PAN, which is a reservoir for $\mathrm{NO}_{\mathrm{x}}$, to convert to $\mathrm{NO}_{\mathrm{x}}$. Since $\mathrm{NO}_{2}$ acts as Rayleigh scatterer and reduces visibility, early-season visibility was improved (see trendlines in Figure 8(a) and Figure 8(c)). However, as summer progressed and temperatures increased, production of secondary pollutants increased and PAN became earlier and a slightly enhanced source for increasing visibility-reducing $\mathrm{NO}_{2}$ concentrations. Due to the wetter conditions aerosols swelled, again contributing to reduced visibility. Overall, the results suggest to expect visibility and haze index will be degraded in the future starting in the late main season at same ship emissions.

\section{Discussion and Conclusions}

The mandate of the National Park Service is to preserve natural resources for current and future generations, while still allowing for visitor use and enjoyment. Due to a lack of roads in, or connecting areas to, Glacier Bay, cruise ships are an important means by which visitors access the park. In 2014, cruise ships provided access for over 470,000 passengers, constituting over $95 \%$ of all visitors to the park. Yet cruise ships emit pollutants in the form of precursor gases and primary particles, some of which may form haze. The naturally forming inversions in Glacier Bay [12] trap and accumulate these pollutants, which become visible as brown layers or white haze layers. Producing haze in such pristine areas [11] runs counter to the NPS mandate of both preserving air quality and providing for high-quality visitor experiences. A key attribute is that the climate in which these pollutants and particles are emitted can largely dictate the presence or severity of haze and thus their impact to air quality and visitor experience.

While park managers must remain privy to resource impacts that occur on a daily or other short-term timeframes, planning strategies and documents, including those for cruise-ship tourism, generally occur on long time scales. For example, cruise ships competitively apply for entry permits to provide concessions to visitors in Glacier Bay as part of a concessions prospectus. The most recent concessions contracts, which are written with resource stewardship contingencies to maximize protection of resources including air quality, encompassed 2009 to 2019 [66]. Thus, the NPS has to reassess how to manage the park in the next decade. However, decadalscale climate changes are expected [24] [67]. Thus, a key aspect of adaptability by the NPS is to assess how resources may be affected by visitor use under a changing climate at these time scales.

This study assessed near-term climate-change impacts on inversions and visibility during the tourist season (15 May-15 September) in Glacier Bay. CESM RCP4.5 simulations were downscaled with WRF/Chem over Southeast Alaska for the seasons of 2006 to 2012 (CTL) and 2026 to 2030 (SCE). The downscaled data served to determine climatologies of various inversion and visibility relevant quantities. Cruise-ship activities, and thus emissions, were constant between the two periods thereby ensuring that all impacts on inversions and visibility were due to atmospheric climate change only.

The similar seasonal-spatial means in inversion and visibility relevant quantities in the park or Glacier Bay in contemporary vs. future conditions illustrate that spatial-temporal averages may pretend that a region will not experience climate change. However, the temporal analysis revealed locally notable or even significant climatechange impacts. This means local climate change may manifest at different spatial/temporal scales than seasonal-regional means. Even within a large region like Southeast Alaksa, local climate may change in different directions due to land-cover characteristics. For example, the changes in Glacier Bay were less, on average, than in most of the Tongass National Forest, which warmed notably and in some places significantly. The presence of large glaciers and water surfaces namely retarded warming and diminished climate change locally. We conclude that as long as tidal glaciers still exist in Glacier Bay, the near-surface ABL conditions may become more stable under calm wind conditions over Glacier Bay in a warming climate.

While the locations of the highest/lowest tourist-season mean pollutant concentrations remained largely the same, in part because the locations of strongest/weakest inversions were similar in the future, and the cruise-ship emissions remained identical, we found some significant changes in the nature of inversions. These changes resulted in somewhat conflicting inversion dynamics. For example, inversion duration is expected to be $2 \mathrm{~h}$ to $9 \mathrm{~h}$ shorter due to the enhanced sensible heat and water vapor destabilizing the lower ABL. Thus, less time exists for 
pollutant and particle accumulation, which reduces the likelihood of haze formation. On the other hand, reduced wind speeds increased the frequency of inversion formation, and, once formed, average inversion strength in-

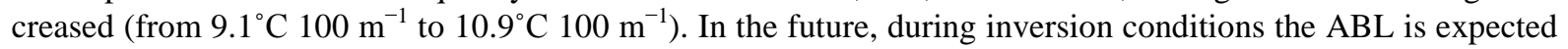
to be more stable, while it will be less stable otherwise due to the on average wetter and warmer conditions than contemporary.

Some of the physical and chemical processes occurring in response to climate change are likely offsetting in terms of visibility and haze formation due to the complex nature of chemical reactions and concurrent processes. Our study revealed that $\mathrm{NO}_{\mathrm{x}}$ concentrations at ship height in Glacier Bay, even though being sensitive to climate change, were strongly governed by the local emissions in Glacier Bay. The linear trendlines calculated over the seasons indicated that changes in visibility occurred to a large degree from the altered fate of PM. Enhanced sensible heat and water vapor led to more frequent breakup of inversions, hence lower concentrations at the beginning of the season. Later in the season, these more frequent breakups and lower $\mathrm{PM}_{10}$ concentrations in the presence of the wetter conditions led to earlier swelling and a shift from $\mathrm{PM}_{2.5}$ to $\mathrm{PM}_{10}$ as also found by others (e.g., [10] [53] [65]).

In summary, the destabilization due to on-average wetter and warmer conditions and enhanced wind shear improved visibility at the beginning of the season. On the contrary, as the season progressed the partitioning among chemical processes shifted the system towards reduced visibility due to more $\mathrm{NO}_{2}$ (and less PAN) under the warmer and wetter future than under contemporary conditions. The calmer winds enhanced removal of coarse particles by sedimentation. Towards the end of the season, the wetter conditions contributed strongly to decreased visibility by swelling and consequent increase in $\mathrm{PM}_{10}$ (Figure 6 and Figure 8).

A major conclusion is that changes in inversion strength, height, or duration showed no direct (linear) correlation to changes in pollutant concentrations due to counteracting processes. The altered pattern and amounts of precipitation contributed to changes in visibility-relevant pollutant-concentration distributions and affected removal/persistence of pollutants in Glacier Bay as well. On a side note, the downscaled precipitation climatologies also suggested more severe drought and flood conditions should be expected for the park with changing climate.

Ultimately, under changing climate, visibility in Glacier Bay will likely degrade stronger than contemporary as the tourist season progresses. This temporal degradation of visibility is due to the climatological increase of humidity and cyclone frequency towards the end of the season. Under the assumed climate change, this general feature would persist, but with improved (degraded) visibility at the onset (end) of the tourist season due to the warmer, wetter and calmer future conditions. By extension, then, the impacts to visitor experience is likely going to depend more on visit timing as climate changes.

The National Park Service could adapt to climate change by generating operating conditions of cruise ships, such as contracts that encourage reduction of $\mathrm{NO}_{\mathrm{x}}$ emissions over the next decades to offset expected climate impacts, although these improvements will ultimately be realized should regulations for Emissions Control Area be implemented for the Pacific coast region.

\section{Acknowledgements}

We thank Gerhard Kramm, Michael A. Pirhalla and the anonymous reviewers for fruitful discussions, the Geophysical Institute's Arctic Region Supercomputing Center at the University of Alaska Fairbanks, the National Park Service (Cooperative Ecosystem Studies Unit Agreement \#P11AT30883/P11AC90465), and the National Center for Atmospheric Research for computational support, for financial support, and providing the CESM projections, respectively.

\section{References}

[1] Anisimov, O.A., Vaughan, D.G., Callaghan, T.V., et al. (2007) Polar Regions (Arctic and Antarctic). In: Parry, M.L., Canziani, O.F., Palutikof, J.P., van der Linden, P.J. and Hanson, C.E., Eds., Climate Change 2007: Impacts, Adaptation and Vulnerability. Contribution of Working Group II to the Fourth Assessment Report of the Intergovernmental Panel on Climate Change. Cambridge University Press, Cambridge, 653-685.

[2] Reeves, R.R., Ewins, P.J., Agbayani, S., Heide-Jørgensen, M.P., Kovacs, K.M., et al. (2014) Distribution of Endemic Cetaceans in Relation to Hydrocarbon Development and Commercial Shipping in a Warming Arctic. Marine Policy, 44, 375-389. 
http://dx.doi.org/10.1016/j.marpol.2013.10.005

[3] CMTS (2014) Ten-Year Projection Study of Maritime Activity in the U.S. Arctic. http://www.cmts.gov/downloads/Executive_Summary_CMTS_10-Year_Arctic_Maritime_Activity_Projection_Report. pdf

[4] National Park System Advisory Board Science Committee (2012) Revisiting Leopold: Resource Stewardship in the National Parks. http://www.nps.gov/calltoaction/PDF/LeopoldReport_2012.pdf

[5] Cole, D.N. and Yung, L. (2010) Beyond Naturalness: Rethinking Park and Wilderness Stewardship in an Era of Rapid Change. Island Press, Washington DC, 287 p.

[6] NPS (2009) Glacier Bay National Park and Preserve Foundation Statement. http://www.nps.gov/glba/learn/management/upload/GLBA Foundation.pdf.

[7] Vaughan, D.G., Comiso, J.C., Allison, I., Carrasco, J., Kaser, G., Kwok, R., Mote, P., Murray, T., Paul, F., Ren, J., Rignot, E. and Solomina, O. (2013) Observations: Cryosphere. In: Stocker, T.F., Qin, D., Plattner, G.-K., et al., Eds., Climate Change 2013: The Physical Science Basis. Contribution of Working Group I to the Fifth Assessment Report of the Intergovernmental Panel on Climate Change, Cambridge, UK and New York, US, 317-382.

[8] Eijgelaar, E., Thaper, C. and Peeters, P. (2010) Antarctic Cruise Tourism: The Paradoxes of Ambassadorship, "Last Chance Tourism” and Greenhouse Gas Emissions. Journal of Sustainable Tourism, 18, 337-354. http://dx.doi.org/10.1080/09669581003653534

[9] Eyring, V., Köhler, H.W., van Aardenne, J. and Lauer, A. (2005) Emissions from International Shipping: 1. The Last 50 Years. Journal of Geophysical Research, 110, Article ID: D17305.

[10] Seinfeld, J.H. and Pandis, S.N. (1997) Atmospheric Chemistry and Physics, from Air Pollution to Climate Change, John Wiley \& Sons, New York, 1326 p.

[11] Mölders, N., Gende, S. and Pirhalla, M.A. (2013) Assessment of Cruise-Ship Activity Influences on Emissions, Air Quality, and Visibility in Glacier Bay National Park. Atmospheric Pollution Research, 4, 435-445.

[12] Pirhalla, M.A., Gende, S. and Mölders, N. (2014) Fate of Particulate Matter from Cruise-Ship Emissions in Glacier Bay during the 2008 Tourist Season. Journal of Environmental Protection, 4, 1235-1254. http://dx.doi.org/10.4236/jep.2014.512118

[13] Li, Z., Bhatt, U.S. and Mölders, N. (2008) Impact of Doubled $\mathrm{CO}_{2}$ on the Interaction between the Global and Regional Water Cycles in Four Study Regions. Climate Dynamics, 30, 255-275. http://dx.doi.org/10.1007/s00382-007-0283-4

[14] (2009) Global Climate Change Impacts in the United States. In: Karl, T.R., Melillo, J.M. and Peterson, T.C., Eds., United States Global Change Research Program, Cambridge University Press, New York.

[15] Mölders, N. (2011) Land-Use and Land-Cover Changes_-Impact on Climate and Air Quality. Springer, Heidelberg, $193 \mathrm{p}$.

[16] Jacob, D.J. and Winner, D.A. (2009) Effect of Climate Change on Air Quality. Atmospheric Environment, 43, 51-63. http://dx.doi.org/10.1016/j.atmosenv.2008.09.051

[17] Gidhagen, L., Engardt, M., Lövenheim, B. and Johansson, C. (2012) Modeling Effects of Climate Change on Air Quality and Population Exposure in Urban Planning Scenarios. Advances in Meteorology, 2012, Article ID: 240894. http://dx.doi.org/10.1155/2012/240894

[18] Menut, L., Tripathi, O.P., Colette, A., Vautard, R., Flaounas, E., et al. (2013) Evaluation of Regional Climate Simulations for Air Quality Modelling Purposes. Climate Dynamics, 40, 2515-2533. http://dx.doi.org/10.1007/s00382-012-1345-9

[19] Gustafson, W.I. and Ruby Leung, L. (2007) Regional Downscaling for Air Quality Assessment. Bulletin of the American Meteorological Society, 88, 1215-1227. http://dx.doi.org/10.1175/BAMS-88-8-1215

[20] Zhang, Y., Liu, X.-H., Olsen, K.M., Wang, W.X., Do, B.A., et al. (2010) Responses of Future Air Quality to Emission Controls over North Carolina, Part II: Analyses of Future-Year Predictions and Their Policy Implications. Atmospheric Environment, 44, 2767-2779. http://dx.doi.org/10.1016/j.atmosenv.2010.03.022

[21] Paeth, H. and Mannig, B. (2013) On the Added Value of Regional Climate Modeling in Climate Change Assessment. Climate Dynamics, 41, 1057-1066. http://dx.doi.org/10.1007/s00382-012-1517-7

[22] Xue, Y.K., Janjić, Z., Dudhia, J., Vasic, R. and De Sales, F. (2014) A Review on Regional Dynamical Downscaling in Intraseasonal to Seasonal Simulation/Prediction and Major Factors That Affect Downscaling Ability. Atmospheric Research, 147-148, 68-85. http://dx.doi.org/10.1016/j.atmosres.2014.05.001

[23] Lamarque, J.-F., Emmons, L.K., Hess, P.G., Kinnison, D.E., Tilmes, S., et al. (2012) CAM-Chem: Description and Evaluation of Interactive Atmospheric Chemistry in the Community Earth System Model. Geoscientific Model Development, 5, 369-411. http://dx.doi.org/10.5194/gmd-5-369-2012 
[24] Meehl, G.A., Washington, W.M., Arblaster, J.M., Hu, A.X., Teng, H.Y., et al. (2013) Climate Change Projections in CESM1 (CAM5) Compared to CCSM4. Journal of Climate, 26, 6287-6308. http://dx.doi.org/10.1175/JCLI-D-12-00572.1

[25] van Vuuren, D.P., Edmonds, J., Kainuma, K., Riahi, K., Thomson, A., et al. (2011) The Representative Concentration Pathways: An Overview. Climatic Change, 109, 5-31. http://dx.doi.org/10.1007/s10584-011-0148-z

[26] Skamarock, W.C., Klemp, J.B., Dudhia, J., Gill, D.O., Barker, D., et al. (2008) A Description of the Advanced Research WRF Version 3. NCAR/TN, 125 p. http://www2.mmm.ucar.edu/wrf/users/docs/arw_v3.pdf

[27] Grell, G.A., Peckham, S.E., Schmitz, R., McKeen, S.A., Frost, G., et al. (2005) Fully Coupled "Online” Chemistry within the WRF Model. Atmospheric Environment, 39, 6957-6975. http://dx.doi.org/10.1016/j.atmosenv.2005.04.027

[28] Peckham, S.E., Fast, J., Schmitz, R., Barth, M., Pfister, G., et al. (2011) WRF/Chem Version 3.3 User’s Guide. 96 p. http://ruc.noaa.gov/wrf/WG11/wrf_tutorial_2011/WRFchem_Users_Guide_v33_18july2011.pdf

[29] Mölders, N., Porter, S.E., Cahill, C.F. and Grell, G.A. (2010) Influence of Ship Emissions on Air Quality and Input of Contaminants in Southern Alaska National Parks and Wilderness Areas during the 2006 Tourist Season. Atmospheric Environment, 44, 1400-1413. http://dx.doi.org/10.1016/j.atmosenv.2010.02.003

[30] Mölders, N., Tran, H.N.Q., Quinn, P., et al. (2011) Assessment of WRF/Chem to Capture Sub-Arctic Boundary Layer Characteristics during Low Solar Irradiation Using Radiosonde, Sodar, and Station Data. Atmospheric Pollution Research, 2, 283-299.

[31] Mölders, N., Tran, H.N.Q., Cahill, C.F., Leelasakultum, K. and Tran, T.T. (2012) Assessment of WRF/Chem PM 2.5 Forecasts Using Mobile and Fixed Location Data from the Fairbanks, Alaska Winter 2008/09 Field Campaign. Atmospheric Pollution Research, 3, 180-191.

[32] Harris, I., Jones, P.D., Osborn, T.J. and Lister, D.H. (2013) Updated High-Resolution Grids of Monthly Climatic Observations-The CRU TS3.10 Dataset. International Journal of Climatology, 34, 623-642. http://dx.doi.org/10.1002/joc.3711

[33] Mölders, N., Bruyère, C.L., Gende, S. and Pirhalla, M.A. (2014) Assessment of the 2006-2012 Climatological Fields and Mesoscale Features from Regional Downscaling of CESM Data by WRF-Chem over Southeast Alaska. Atmospheric and Climate Sciences, 4, 589-613. http://dx.doi.org/10.4236/acs.2014.44053

[34] Erler, A.R., Peltier, W.R. and D’Orgeville, M. (2014) Dynamically Downscaled High-Resolution Hydroclimate Projections for Western Canada. Journal of Climate, 28, 423-450. http://dx.doi.org/10.1175/JCLI-D-14-00174.1

[35] Hong, S.-Y. and Lim, J.-O.J. (2006) The WRF Single-Moment 6-Class Microphysics Scheme (WSM6). Journal Korean Meteorological Society, 42, 129-151. http://www.citeulike.org/user/bschwedler/article/9361791

[36] Grell, G.A. and Dévényi, D. (2002) A Generalized Approach to Parameterizing Convection. Geophysical Research Letters, 29.

[37] Chou, M.-D. and Suarez, M.J. (1994) An Efficient Thermal Infrared Radiation Parameterization for Use in General Circulation Models. Technical Report, 85 p. http://citeseerx.ist.psu.edu/viewdoc/summary?doi=10.1.1.26.4850

[38] Mlawer, E.J., Taubman, S.J., Brown, P.D., Iacono, M.J. and Clough, S.A. (1997) Radiative Transfer for Inhomogeneous Atmospheres: RRTM, a Validated Correlated-K Model for the Longwave. Journal of Geophysical Research, 102, 16663-16682. http://dx.doi.org/10.1029/97JD00237

[39] Barnard, J., Fast, J., Paredes-Miranda, G., Arnott, W. and Laskin, A. (2010) Technical Note: Evaluation of the WRFChem “Aerosol Chemical to Aerosol Optical Properties” Module Using Data from the Milagro Campaign. Atmospheric Chemistry and Physics, 10, 7325-7340. http://dx.doi.org/10.5194/acp-10-7325-2010

[40] Janjić, Z.I. (2002) Nonsingular Implementation of the Mellor-Yamada Level 2.5 Scheme in the NCEP Meso Model. NCEP Office Note, 61 p. http://www.emc.ncep.noaa.gov/officenotes/newernotes/on437.pdf

[41] Chen, F. and Dudhia, J. (2000) Coupling an Advanced Land-Surface/Hydrology Model with the Penn State/NCAR MM5 Modeling System. Part I: Model Description and Implementation. Monthly Weather Review, 129, 569-585. http://dx.doi.org/10.1175/1520-0493(2001)129<0569:CAALSH>2.0.CO;2

[42] Stockwell, W.R., Middleton, P., Chang, J.S. and Tang, X. (1990) The Second-Generation Regional Acid Deposition Model Chemical Mechanism for Regional Air Quality Modeling. Journal Geophysical Research, 95, 16343-16367. http://dx.doi.org/10.1029/JD095iD10p16343

[43] Madronich, S. (1987) Photodissociation in the Atmosphere: 1. Actinic Flux and the Effects of Ground Reflections and Clouds. Journal Geophysical Research, 92, 9740-9752. http://dx.doi.org/10.1029/JD092iD08p09740

[44] Wesely, M.L. (1989) Parameterization of Surface Resistances to Gaseous Dry Deposition in Regional-Scale Numerical Models. Atmospheric Environment, 23, 1293-1304. http://dx.doi.org/10.1016/0004-6981(89)90153-4

[45] Ackermann, I.J., Hass, H., Memmesheimer, M., Ebel, A., Binkowski, F.S., et al. (1998) Modal Aerosol Dynamics Model for Europe: Development and First Applications. Atmospheric Environment, 32, 2981-2299. 
http://dx.doi.org/10.1016/S1352-2310(98)00006-5

[46] Schell, B., Ackermann, I.J., Hass, H., Binkowski, F.S. and Ebel, A. (2001) Modeling the Formation of Secondary Organic Aerosol within a Comprehensive Air Quality Model System. Journal of Geophysical Research, 106, 2827528293. http://dx.doi.org/10.1029/2001JD000384

[47] Simpson, D., Guenther, A., Hewitt, C.N. and Steinbrecher, R. (1995) Biogenic Emissions in Europe 1. Estimates and Uncertainties. Journal Geophysical Research, 100, 22875-22890. http://dx.doi.org/10.1029/95JD02368

[48] Guenther, A. (1997) Seasonal and Spatial Variations in Natural Volatile Organic Compund Emissions. Ecological Applications, 7, 34-45. http://dx.doi.org/10.1890/1051-0761(1997)007[0034:SASVIN]2.0.CO;2

[49] Webb, K. and Gende, S.M. (2015) Activity Patterns and Speeds of Large Cruise Ships in Southeast Alaska. Coastal Management, 43, 67-83. http://dx.doi.org/10.1080/08920753.2014.989148

[50] Meinshausen, M., Smith, S.J., Calvin, K., Daniel, J.S., Kainuma, M.L.T., et al. (2011) The RCP Greenhouse Gas Concentrations and Their Extensions from 1765 to 2300. Climatic Change, 109, 213-241. http://dx.doi.org/10.1007/s10584-011-0156-z

[51] Keppel-Aleks, G., Randerson, J.T., Lindsay, K., Stephens, B.B., Keith Moore, J., et al. (2013) Atmospheric Carbon Dioxide Variability in the Community Earth System Model: Evaluation and Transient Dynamics during the Twentieth and Twenty-First Centuries. Journal of Climate, 26, 4447-4475. http://dx.doi.org/10.1175/JCLI-D-12-00589.1

[52] Buhaug, Ø., Corbett, J.J., Endresen, Ø., et al. (2009) Second IMO GHG Study 2009. International Maritime Organization, London.

http://www.imo.org/OurWork/Environment/PollutionPrevention/AirPollution/Pages/Second-IMO-GHG-Study-2009.as px

[53] EPA (2007) Guidance on the Use of Models and Other Analyses for Demonstrating Attainment of Air Quality Goals for Ozone, $\mathrm{PM}_{2.5}$, and Regional Haze. Technical Notes, $262 \mathrm{p}$. http://www.epa.gov/scram001/guidance/guide/final-03-pm-rh-guidance.pdf.

[54] Kim, J., Waliser, D.E., Mattmann, C.A., Mearns, L.O., Goodale, C.E., et al. (2013) Evaluation of the Surface Climatology over the Conterminous United States in the North American Regional Climate Change Assessment Program Hindcast Experiment Using a Regional Climate Model Evaluation System. Journal of Climate, 26, 5698-5715. http://dx.doi.org/10.1175/JCLI-D-12-00452.1

[55] Li, H.Q., Kanamitsu, M., Hong, S.-Y., Yoshimura, K., Cayan, D.R., et al. (2014) Projected Climate Change Scenario over California by a Regional Ocean-Atmosphere Coupled Model System. Climatic Change, 122, 609-619. http://dx.doi.org/10.1007/s10584-013-1025-8

[56] Smirnov, D., Newman, M. and Alexander, M.A. (2013) Investigating the Role of Ocean-Atmosphere Coupling in the North Pacific Ocean. Journal of Climate, 27, 592-606. http://dx.doi.org/10.1175/JCLI-D-13-00123.1

[57] Mölders, N. and Kramm, G. (2010) A Case Study on Wintertime Inversions in Interior Alaska with WRF. Atmospheric Research, 95, 314-332. http://dx.doi.org/10.1016/j.atmosres.2009.06.002

[58] Mölders, N. (2013) Investigations on the Impact of Single Direct and Indirect, and Multiple Emission-Control Measures on Cold-Season Near-Surface $\mathrm{PM}_{2.5}$ Concentrations in Fairbanks, Alaska. Atmospheric Pollution Research, 4, 87-100. http://dx.doi.org/10.5094/APR.2013.009

[59] Zhao, Z., Chen, S.-H., Kleeman, M.J. and Mahmud, A. (2011) The Impact of Climate Change on Air Quality-Related Meteorological Conditions in California. Part II: Present versus Future Time Simulation Analysis. Journal of Climate, 24, 3362-3376. http://dx.doi.org/10.1175/2010JCLI3850.1

[60] Dawson, J.P., Bloomer, B.J., Winner, D.A. and Weaver, C.P. (2013) Understanding the Meteorological Drivers of U.S. Particulate Matter Concentrations in a Changing Climate. Bulletin of the American Meteorological Society, 95, 521532. http://dx.doi.org/10.1175/BAMS-D-12-00181.1

[61] van Dijk, S.M., Gut, A., Kirkman, G.A., Gomes, N.M., Meixner, F.X., et al. (2002) Biogenic No Emissions from Forest and Pasture Soils: Relating Laboratory Studies to Field Measurements. Journal of Geophysical Research, 107, LBA 25-1-LBA 25-11.

[62] Jacobson, M.Z. (2007) Fundamentals of Atmospheric Modeling. Cambridge University Press, Cambridge, 813 p.

[63] Lovejoy, E.R., Hanson, D.R. and Huey, L.G. (1996) Kinetics and Products of the Gas-Phase Reaction of $\mathrm{SO}_{3}$ with Water. The Journal of Physical Chemistry, 100, 19911-19916. http://dx.doi.org/10.1021/jp962414d

[64] Fiedler, V., Nau, R., Ludmann, S., Arnold, F., Schlager, H. and Stohl, A. (2009) East Asian $\mathrm{SO}_{2}$ Pollution Plume over Europe-Part 1: Airborne Trace Gas Measurements and Source Identification by Particle Dispersion Model Simulations. Atmospheric Chemistry and Physics, 9, 4717-4728. http://dx.doi.org/10.5194/acp-9-4717-2009

[65] Tran, H.N.Q. and Mölders, N. (2011) Investigations on Meteorological Conditions for Elevated PM 2.5 in Fairbanks, Alaska. Atmospheric Research, 99, 39-49. http://dx.doi.org/10.1016/j.atmosres.2010.08.028 
[66] NPS (2015) Glacier Bay Cruise Ship Prospectus.

http://www.nps.gov/glba/learn/management/cruise-ship-prospectus-glba-cs-08.htm.

[67] Meehl, G.A., Hu, A.X. and Santer, B.D. (2009) The Mid-1970s Climate Shift in the Pacific and the Relative Roles of Forced Versus Inherent Decadal Variability. Journal of Climate, 22, 780-792.

http://dx.doi.org/10.1175/2008JCLI2552.1 